IZA DP No. 5273

Domestic Violence and Labor Market Outcomes:

Evidence from a Mixed-Race Developing Country

Gustavo Canavire-Bacarreza

Fernando Rios Avila

October 2010 


\title{
Domestic Violence and Labor Market Outcomes: Evidence from a Mixed-Race Developing Country
}

\author{
Gustavo Canavire-Bacarreza \\ Georgia State University \\ and IZA
}

\author{
Fernando Rios Avila \\ Georgia State University
}

\author{
Discussion Paper No. 5273 \\ October 2010
}

\author{
IZA \\ P.O. Box 7240 \\ 53072 Bonn \\ Germany \\ Phone: +49-228-3894-0 \\ Fax: +49-228-3894-180 \\ E-mail: iza@iza.org
}

Any opinions expressed here are those of the author(s) and not those of IZA. Research published in this series may include views on policy, but the institute itself takes no institutional policy positions.

The Institute for the Study of Labor (IZA) in Bonn is a local and virtual international research center and a place of communication between science, politics and business. IZA is an independent nonprofit organization supported by Deutsche Post Foundation. The center is associated with the University of Bonn and offers a stimulating research environment through its international network, workshops and conferences, data service, project support, research visits and doctoral program. IZA engages in (i) original and internationally competitive research in all fields of labor economics, (ii) development of policy concepts, and (iii) dissemination of research results and concepts to the interested public.

IZA Discussion Papers often represent preliminary work and are circulated to encourage discussion. Citation of such a paper should account for its provisional character. A revised version may be available directly from the author. 
IZA Discussion Paper No. 5273

October 2010

\section{ABSTRACT \\ Domestic Violence and Labor Market Outcomes: Evidence from a Mixed-Race Developing Country}

This study investigates the heterogeneous effects of domestic violence over labor markets in an ethnically fragmented country such as Bolivia. Among developing countries, Bolivia "excels" in having one of the highest levels of domestic violence in the region. Anecdotal evidence and empirical evidence suggest that response to domestic violence is not homogeneous across different ethnic groups. Using information from the Demographic and Health Survey (DHS) for Bolivia, we examine the heterogeneous impacts of domestic violence over one of the key labor market outcomes such as employment. We employ a probabilistic decision model and treatment regression techniques to examine this effect. We claim that the impact of domestic violence on labor markets is limited among indigenous people, given that violence is, to some extent, socially recognized and accepted. We find that for most of the cases, indigenous women are less responsive to domestic violence than nonindigenous ones, except for groups with a high income level. Our results are robust for alternative methodologies to address possible endogeneity problems.

JEL Classification: J15, J71

Keywords: labor markets, domestic violence, Bolivia, indigenous

Corresponding author:

Gustavo Canavire-Bacarreza

Andrew Young School of Policy Studies

Georgia State University

P.O. Box 3992

Atlanta, GA 30302-3992

USA

E-mail: gcanavire@ucb.edu.bo

\footnotetext{
* The authors thank Barry Hirsch and Rachana Bhatt for their helpful comments. Usual disclaimer applies.
} 


\section{Introduction}

Intra-household violence is a very important topic that has been mainly studied by sociologists and criminalists. Its importance has been recognized for being associated with serious problems for public health, human rights and welfare. Women and children are the principal victims, especially in developing countries (WHO 2002). Bolivia "excels" for having high levels of domestic violence, ${ }^{2}$ which is particularly an issue in an indigenous population who considers it as a minor problem.

Despite the anecdotal evidence, very little attention was focused on analyzing the effects of violence on topics beyond the physical and psychological safety of women in developing countries. More specifically, literature on the relationships between violence and labor market outcomes, such as wages, labor force participation, and productivity is relatively scarce. ${ }^{3}$

The dichotomy of the violence-labor relationship is indeed very important in Bolivia, not only because of the high levels of domestic violence but also because of the different perceptions between indigenous and non-indigenous populations in urban and rural areas. Anthropological studies, such as Albo (1994), argue that intra-household violence is, to some extent, socially recognized and accepted among indigenous populations, who could be influenced by the so-called "communitarian justice", while non-indigenous people have no particular favoritism in respect to violence.

This law for the Bolivian indigenous population is often based on rules and customs that tolerate, under certain circumstances, husbands beating their wives ${ }^{4}$. Even though the current law in the

\footnotetext{
${ }^{2}$ For instance, $83 \%$ of children are victims of domestic violence at some degree (INE-UNICEF 2007), while the incidence of violence between parents is about 53\% (UDAPE-UNICEF 2008a). Also, according to the Demographic Health Survey 2003 report for Bolivia, at least 54\% of women declared to have been victims to some kind of psychological violence, while $53 \%$ declared to be victim of physical violence.

${ }^{3}$ Moreover, the existing theory is ambiguous at defining the relationship and direction of causality between labor market outcomes and violence. Some authors such as Molm (1997) agree that violence is a consequence of men losing their role in households, while others argue (Kalmuss and Straus, 1990) that work help to alleviate and reduce the incidence of violence through bargaining, while the last ones, that work is an escape from violent households.

4 According to Machicado (2010), all the activities classified as intra household conflicts and domestic violence are considered only as minor problem, and are punished only with communitarian justice.
} 
country establishes the penalties for intra-household violence, with an important institutional response from the public sector preventing and fighting domestic violence (UDAPE-UNICEF 2008b), there are some segments of the population where the law of the land does not hold, leading to the reign of "communitarian justice" . Moreover, in the last modification of the political constitution of Bolivia, the communitarian justice is actually recognized and accepted as part of the legal system.

Under these considerations, in this paper we examine the impact of domestic violence inside marriage in a mixed-race country, such as Bolivia, focusing on the potential differential effect between indigenous and non-indigenous couples. The hypothesis behind the analysis is that indigenous people might be less sensitive to husband-wife violence, compared to their nonindigenous counterparts, when deciding whether or not to participate in the labor market, because they consider domestic violence as a "normal" behavior from their partners.

Using a probit model we estimate how violence relates to the decisions of exiting the labor market after considering all other factors that generally affect female labor market participation. Given the potential endogeneity problem, we applied a probit instrumental variable approach using the average incidence of domestic violence in the region as an instrument that is clearly related to the higher risk of domestic violence but would not affect the probability of leaving a job. In addition, we also use a treatment selection model, using factors such as intergenerational violence and acceptance as an exclusion restriction, in order to address the endogeneity problem. Our results are consistent with the intuition of heterogeneous effects of violence on indigenous vs. non-indigenous women. Even though we find a significant effect of violence on exiting jobs, we also find that indigenous women are less responsive to domestic violence when compared to their non-indigenous peers. In addition,

5 "The Communitarian justice is an Institution of Consuetudinary Rights that allows to penalize punishable acts of individuals without intervention of the State, Judges or its bureaucracy, but directly by the community of individuals and their chosen authorities". (Machicado, 2010) It implies the recognition of the traditional juridical practices of indigenous people in Bolivia. 
we confirm the hypothesis that the effects differ inside each group depending on the income position (a proxy for social status) of the women.

The rest of the paper is organized as follows. Section 2 presents a review of the literature on domestic violence. Section 3 presents the descriptive statistics. Section 4 describes the analytical framework and methodology. Section 5 presents the empirical results, and section 6 concludes.

\section{Where do we stand? A brief review of the literature}

Domestic violence is a complex problem that has a negative impact on household welfare, especially on the direct victims. Although these effects can be evident in different aspects, one of the most important aspects examined in the economic literature has been the impact of domestic violence on labor market outcomes, such as productivity and employment. One of the gaps in this literature, however, is that they do not consider heterogeneous impacts (i.e. between ethnic groups), which could affect how victims are influenced by domestic violence, as it is the case between indigenous and non-indigenous people in Bolivia.

The literature on domestic violence and labor force participation has mainly examined their relationships using two different approaches. One strand of the literature considers employment and the generation of income as the triggering factor affecting domestic violence. A second strand of the literature analyzes how domestic violence affects the performance and participation of the victims in the labor market.

In the group of the first approach, authors such as Aizer(2007), Gelles(1976), Bhattacharya et al (2009), Bowlus and Seitz (2006), Macmillian and Gartner (1999), Tauchen et al (1991) and Farmer and Tauchen, and Witte (1995) explain that the decisions of participating in the labor market and generating resources are the ones that affect the incidence of domestic violence in the household. The way domestic violence is affected depends on how the bargaining power and the roles of the household members affect the potential victim's decisions. On the one hand, when the wife earns 
resources, she has more decision power in the household and becomes more independent, which gives her a better position when avoiding violent situations (Kalmuss and Straus 1990). On the other hand, because the wife is gaining this power, the husband might feel that his position is threatened, and he might use coercion (violence) to regain his position (Molm, 1997).

In this sense, most of the authors find that women with more resources and wealth are less likely to remain in an abusive relationship or present relatively lower rates of domestic violence. Therefore the high correlation that exists between social status, income, and violence is of importance in the analysis. Furthermore, Macmillan and Gartner (1999) and Aizer (2007) also find that the potential employment status can work as a signal for reducing the incidence of domestic violence. Macmillan and Gartner (1999) also find that the labor force participation can reduce the risk of violence if the husband also works, but could increase it if he is unemployed.

Some authors, such as Tauchen et al (1991) and Farmer, Tauchen, and Witte (1995), have found no evidence that employment status has any effect on domestic violence. According to this side of the literature, changes on the incidence of domestic violence are triggered by changes in the situations of the household members, in particular of the victims (wives). This analysis implies that the later are exogenous shocks. However, as the second strand of the literature emphasizes, labor market decisions can also be affected by the incidences of domestic violence. This situation complicates the analysis, since both variables might be defining each other simultaneously, and the net effect of the violence would be more difficult to identify.

In the second approach of analysis, many authors (Franzway, 1998; Lloyd, 1997; Lloyd and Taluc, 1999; Meisel, Chandler and Reinzi, 2003; Swanberg and Logan, 2005; Seitz, 1998; Tolman and Wang, 2005) focus on analyzing of the effects of domestic violence on the performance, productivity, and work-related decisions of the victims. According to this approach, violence might affect labor decisions in two possible ways. First, the perpetrator can interfere on the normal 
activities of the victim using coercion, interrupting her, harassing her, or even beating her. These activities might reduce the victim's work performance, reduce her attendance, or increase the subjective costs of hiring her, which could directly translate into fewer hours at work or even job termination. Second, women who suffer from domestic violence are more actively trying to get away from home, and going out to work is an alternative. Although this channel might initially be reflected in higher levels of labor force participation, with its combination with the previous channel, it could be translated to higher levels of job instability and job termination rates.

Considering this approach, the evidence in the literature shows that domestic violence is negatively correlated with earnings and positively related with job exit. Women who suffer from violence present higher rates of unemployment in the past (Lloyd, 1997; Lloyd and Taluc, 1999). Women who are victims of domestic violence present lower rates of employment or work for fewer hours (Meisel, Chandler and Reinzi, 2003; Swanberg and Logan, 2005; Tolman and Wang, 2005).

Despite the problematic situation of domestic violence in Bolivia, to the best of our knowledge, it has been almost nonexistent previous research. The only study that identifies the problem of domestic violence, with emphasis on children's welfare, are the studies by UDAPE-UNICEF (2008a) and INE-UNICEF (2007), which quantify and analyze the determinants of domestic violence against children and the institutional response from the public sector for the prevention of domestic violence.

\section{Data and statistics}

\subsection{Data}

For the purpose of this paper, we use information from the Demographic Health Survey (DHS) of 2003 for Bolivia ${ }^{6}$. This is a national representative survey which focuses on health outcomes for women and children, but also contains basic demographic and socioeconomic information for all

${ }^{6}$ Encuesta Nacional de Demografia y Salud (ENDSA) 2003 in Spanish 
the household members. The main advantage of using this survey is that it provides detailed information on the victims and victimizers of domestic violence, and allows us to focus our analysis on the incidences of domestic violence between husbands and their partners (wives). Although information in respect to violence against husbands is also available, we exclude it from this analysis. Detailed information on violence is only available for a specific group of women in the sample, namely a female population who all are married and/or living as a couple. The survey collects information from 17,654 eligible women, all between 15 to 49 years old.

From the entire sample, we extracted a subsample of 7.842 women aged 15 years old or older who worked during the year and declared being in a committed relationship (married or living in union with someone). Hereafter, the analysis is constrained to this subsample of women.

\subsection{Descriptive Statistics}

According to our estimations, $64.19 \%$ of women in the sample were living in urban areas. These women are characterized as being relatively young (33.69 yrs) and with low levels of education (7.21 yrs). Using self-reported information on language spoken during childhood, $39.82 \%$ of women are classified indigenous. ${ }^{7}$ Considering the characteristics of their households, $79.70 \%$ of the women declared to have children living in the households, while $53.15 \%$ stated they have children under the age of 5. With respect to the labor market status, considering that all women in the sample were working at some point during the year, ${ }^{8} 88.80 \%$ were currently working at time of the interview.

Considering the information across indigenous and non-indigenous people, some characteristics vary substantially. Indigenous women have much lower education (4.15 yrs) compared to nonindigenous people (9.23 yrs). Indigenous women are also more likely to live in households with

\footnotetext{
${ }^{7}$ Even the empirical definition of indigenous population is not clearly established most of the literature follows two identification strategies for indigenous, namely self-identification and native language. Albo (2005) clearly establishes the high correlation of this definition in Bolivia.

${ }^{8}$ From the whole sample, $68.39 \%$ of women had a job at least once during the year
} 
children of any age, $83.54 \%$ compared to $77.16 \%$, or for young children, $60.23 \%$ compared to 48.46\%. The characteristics observed considering areas follow similar patterns.

For the treatment of domestic violence, and given the nature of the survey, we employ self-declared information of violent incidents. This information, however, could be biased for two reasons: first, the nature of being self-declared information usually implies a classical measurement error that could create a bias on the estimations. Second, because women are self-declaring information on such a delicate topic, they may tend to downplay the incidents of domestic violence because they might feel uncomfortable declaring it.

Furthermore, it is possible that those women who have high levels of violence acceptance would tend to under-declare incidents of violence because they consider it to be normal, which could be a particular problem for indigenous women. Ellsberg et al. (2001) therefore argue that the results obtained for the DHS provide a fairly accurate estimation on the incidence of violence compared to more specialized studies. Nevertheless, if there is indeed under-declaration of domestic violence, we should see even greater effects because people who declare it could be the ones suffering the most. We identify two different types of violence against women: physical violence and psychological violence $^{9}$. As we can see, the incidence of physical (55.16\%) and psychological $(55.67 \%)$ violence is almost the same for the different groups. Combining both concepts, the estimations show that $66.12 \%$ women in our sample have suffered of some kind of domestic violence. It is interesting to see that, within all the women in our sample, $23.54 \%$ of women perceive that domestic violence can be justified under certain conditions.

\footnotetext{
${ }^{9}$ The definitions and identifications of these variables can be found in appendix 1.
} 
Table 1. Summary statistics of wives, by area and ethnicity Standard Deviations in parenthesis

\begin{tabular}{|c|c|c|c|c|c|}
\hline Variables & Full Sample & Urban & Rural & Indigenous & $\begin{array}{c}\text { Non } \\
\text { Indigenous }\end{array}$ \\
\hline Age & $\begin{array}{l}33.69 \\
(8.32)\end{array}$ & $\begin{array}{l}33.67 \\
(8.18)\end{array}$ & $\begin{array}{l}33.74 \\
(8.56)\end{array}$ & $\begin{array}{l}34.67 \\
(8.39)\end{array}$ & $\begin{array}{r}33.05 \\
(8.21)\end{array}$ \\
\hline Education in years & $\begin{array}{r}7.21 \\
(4.97)\end{array}$ & $\begin{array}{r}8.65 \\
(4.90)\end{array}$ & $\begin{array}{r}4.63 \\
(3.95)\end{array}$ & $\begin{array}{r}4.15 \\
(3.58)\end{array}$ & $\begin{array}{r}9.23 \\
(4.72)\end{array}$ \\
\hline Indigenous $=1$ & $\begin{array}{r}39.82 \% \\
(0.49)\end{array}$ & $\begin{array}{r}27.10 \% \\
(0.44)\end{array}$ & $\begin{array}{r}62.64 \% \\
(0.48)\end{array}$ & & \\
\hline $\begin{array}{l}\text { HH with Children } \\
\text { older than } 5\end{array}$ & $\begin{array}{r}79.70 \% \\
(0.40)\end{array}$ & $\begin{array}{r}78.86 \% \\
(0.41)\end{array}$ & $\begin{array}{r}81.20 \% \\
(0.39)\end{array}$ & $\begin{array}{r}83.54 \% \\
(0.37)\end{array}$ & $\begin{array}{r}77.16 \% \\
(0.42)\end{array}$ \\
\hline $\begin{array}{l}\mathrm{HH} \text { with Children } \\
\text { younger than } 5\end{array}$ & $\begin{array}{r}53.15 \% \\
(0.50)\end{array}$ & $\begin{array}{r}48.43 \% \\
(0.50)\end{array}$ & $\begin{array}{r}61.61 \% \\
(0.49)\end{array}$ & $\begin{array}{r}60.23 \% \\
(0.49)\end{array}$ & $\begin{array}{r}48.46 \% \\
(0.50)\end{array}$ \\
\hline Currently working & $\begin{array}{r}88.80 \% \\
(0.32)\end{array}$ & $\begin{array}{r}87.90 \% \\
(0.33)\end{array}$ & $\begin{array}{r}90.42 \% \\
(0.29)\end{array}$ & $\begin{array}{r}91.64 \% \\
(0.28)\end{array}$ & $\begin{array}{r}86.93 \% \\
(0.34)\end{array}$ \\
\hline $\begin{array}{l}\text { Physical } \\
\text { Violence }\end{array}$ & $\begin{array}{r}55.16 \% \\
(0.50)\end{array}$ & $\begin{array}{r}55.82 \% \\
(0.50)\end{array}$ & $\begin{array}{r}53.99 \% \\
(0.50)\end{array}$ & $\begin{array}{r}55.40 \% \\
(0.50)\end{array}$ & $\begin{array}{r}55.01 \% \\
(0.50)\end{array}$ \\
\hline $\begin{array}{l}\text { Psychological } \\
\text { Violence }\end{array}$ & $\begin{array}{r}55.67 \% \\
(0.50)\end{array}$ & $\begin{array}{r}56.58 \% \\
(0.50)\end{array}$ & $\begin{array}{r}54.06 \% \\
(0.50)\end{array}$ & $\begin{array}{r}54.15 \% \\
(0.50)\end{array}$ & $\begin{array}{r}56.69 \% \\
(0.50)\end{array}$ \\
\hline Violence Incidence & $\begin{array}{r}66.12 \% \\
(0.47)\end{array}$ & $\begin{array}{r}67.12 \% \\
(0.47)\end{array}$ & $\begin{array}{r}64.32 \% \\
(0.48)\end{array}$ & $\begin{array}{r}64.46 \% \\
(0.48)\end{array}$ & $\begin{array}{r}67.22 \% \\
(0.47)\end{array}$ \\
\hline Accepts Violence & $\begin{array}{r}23.55 \% \\
(0.42)\end{array}$ & $\begin{array}{r}21.20 \% \\
(0.41)\end{array}$ & $\begin{array}{r}27.78 \% \\
(0.45)\end{array}$ & $\begin{array}{r}26.74 \% \\
(0.44)\end{array}$ & $\begin{array}{r}21.45 \% \\
(0.41)\end{array}$ \\
\hline Urban Area & $\begin{array}{r}64.19 \% \\
(0.48)\end{array}$ & & & $\begin{array}{r}43.68 \% \\
(0.50)\end{array}$ & $\begin{array}{r}77.77 \% \\
(0.42)\end{array}$ \\
\hline Number observations & 7842 & 5034 & 2808 & 3123 & 4719 \\
\hline
\end{tabular}

Source: Own estimations based on DHS 2003

Examining the incidence of violence between indigenous and non-indigenous women, we find that indigenous women present with a lower incidence of violence $(64.46 \%)$ than non-indigenous ones (67.22\%). This difference can be basically explained because non-indigenous women present a higher incidence of psychological violence (56.69\% versus $54.15 \%$ ), whereas the incidence of physical violence is almost the same for both groups. It is also interesting to note that the percentage of non-indigenous women who accept domestic violence $(21.45 \%)$ is lower than that for indigenous people $(26.74 \%)$.

When considering our variable of interest, labor market outcome, (100-88.8\%) 11.2\% of women who were working at one point in the year left their jobs. This proportion was relatively higher for urban areas than rural areas (12.1\% versus 9.58\%), but also higher for non-indigenous than indigenous people $(13.07 \%$ versus $8.36 \%)$. 
Table 2. Summary statistics of wives, by violence and labor outcome Standard Deviations in parenthesis

\begin{tabular}{|c|c|c|c|c|c|}
\hline Variables & Full Sample & Suffer Violence & No Violence & Still working & Left job \\
\hline Age & $\begin{array}{l}33.69 \\
(8.32)\end{array}$ & $\begin{array}{l}33.78 \\
(8.28)\end{array}$ & $\begin{array}{l}33.52 \\
(8.39)\end{array}$ & $\begin{array}{l}34.19 \\
(8.19)\end{array}$ & $\begin{array}{l}29.73 \\
(8.24)\end{array}$ \\
\hline Education in years & $\begin{array}{r}7.21 \\
(4.97)\end{array}$ & $\begin{array}{r}7.02 \\
(4.81)\end{array}$ & $\begin{array}{r}7.57 \\
(5.25)\end{array}$ & $\begin{array}{r}7.16 \\
(5.03)\end{array}$ & $\begin{array}{r}7.57 \\
(4.47)\end{array}$ \\
\hline Indigenous $=1$ & $\begin{array}{r}39.82 \% \\
(0.49)\end{array}$ & $\begin{array}{r}38.82 \% \\
(0.49)\end{array}$ & $\begin{array}{r}41.78 \% \\
(0.49)\end{array}$ & $\begin{array}{r}41.10 \% \\
(0.49)\end{array}$ & $\begin{array}{r}29.73 \% \\
(0.46)\end{array}$ \\
\hline $\begin{array}{l}\text { HH with Children } \\
\text { older than } 5\end{array}$ & $\begin{array}{r}79.70 \% \\
(0.40)\end{array}$ & $\begin{array}{r}82.01 \% \\
(0.38)\end{array}$ & $\begin{array}{r}75.20 \% \\
(0.43)\end{array}$ & $\begin{array}{r}81.56 \% \\
(0.39)\end{array}$ & $\begin{array}{r}64.92 \% \\
(0.48)\end{array}$ \\
\hline $\begin{array}{l}\text { HH with Children } \\
\text { younger than } 5\end{array}$ & $\begin{array}{r}53.15 \% \\
(0.50)\end{array}$ & $\begin{array}{r}52.98 \% \\
(0.50)\end{array}$ & $\begin{array}{r}53.48 \% \\
(0.50)\end{array}$ & $\begin{array}{r}52.34 \% \\
(0.50)\end{array}$ & $\begin{array}{r}59.57 \% \\
(0.49)\end{array}$ \\
\hline Currently working & $\begin{array}{r}88.80 \% \\
(0.32)\end{array}$ & $\begin{array}{r}87.91 \% \\
(0.33)\end{array}$ & $\begin{array}{r}90.55 \% \\
(0.29)\end{array}$ & & \\
\hline $\begin{array}{l}\text { Physical } \\
\text { Violence }\end{array}$ & $\begin{array}{r}55.16 \% \\
(0.50)\end{array}$ & $\begin{array}{r}83.43 \% \\
(0.37)\end{array}$ & & $\begin{array}{r}54.71 \% \\
(0.50)\end{array}$ & $\begin{array}{r}58.77 \% \\
(0.49)\end{array}$ \\
\hline Psychological & $55.67 \%$ & $84.20 \%$ & & $55.18 \%$ & $59.57 \%$ \\
\hline Violence & $(0.50)$ & $(0.36)$ & & $(0.50)$ & $(0.49)$ \\
\hline Violence Incidence & $\begin{array}{r}66.12 \% \\
(0.47)\end{array}$ & & & $\begin{array}{r}65.45 \% \\
(0.48)\end{array}$ & $\begin{array}{r}71.41 \% \\
(0.45)\end{array}$ \\
\hline Accepts Violence & $\begin{array}{r}23.55 \% \\
(0.42)\end{array}$ & $\begin{array}{r}25.77 \% \\
(0.44)\end{array}$ & $\begin{array}{r}19.23 \% \\
(0.39)\end{array}$ & $\begin{array}{r}23.36 \% \\
(0.42)\end{array}$ & $\begin{array}{r}25.06 \% \\
(0.43)\end{array}$ \\
\hline Urban Area & $\begin{array}{r}64.19 \% \\
(0.48)\end{array}$ & $\begin{array}{r}65.17 \% \\
(0.48)\end{array}$ & $\begin{array}{r}62.29 \% \\
(0.48)\end{array}$ & $\begin{array}{r}63.54 \% \\
(0.48)\end{array}$ & $\begin{array}{r}69.36 \% \\
(0.46)\end{array}$ \\
\hline Number observations & 7842 & 5185 & 2657 & 6964 & 878 \\
\hline
\end{tabular}

Source: Own estimations based on DHS 2003

Some insights with respect to the effects of violence can be observed by comparing the groups that suffered from violence to those who did not. With respect to age and education, both groups look alike, with a slightly lower share of indigenous people in the group that suffered violence. The group that suffered violence, however, presents a rate of 2.64\% (12.09\%-9.45\%) higher of women leaving their jobs. It is not surprising to see that the ratio of women accepting violence is higher among women who actually suffered from violence.

The final question of interest here is to understand what makes women who left their jobs different from the one who kept working. The first thing we see is that women who are victims of domestic violence were younger than average $(29.73 \mathrm{yrs})$, that the proportion of indigenous people was lower in this particular group, and that their households were less likely to have older kids living in them. Women who left their jobs are also characterized as being subject to higher rates of domestic 
violence. It also seems that there is a higher rate of women accepting violence among those who left their jobs, compared to those who kept working.

\section{Analytic framework and Methodology}

Becker (1965) states that a member of a family/household decides to work if the available wage in the job market $\left(\mathrm{w}_{\mathrm{m}}\right)$ is higher than the opportunity cost when producing home goods $\left(\mathrm{w}_{\mathrm{h}}\right)$. This can also be generalized that one would decide to work if the utility of working $\left(u_{m}\right)$, including wages and the utility of working itself, is higher than the overall utility of staying at home $\left(u_{b}\right)$. Under this assumption, the decision to work or not can be estimated using a binary choice model, such that:

$$
P(\text { work }=1)=P\left(u_{w}>u_{h}\right)=P\left(u_{w}-u_{h}>0\right)
$$

Assuming that the utility of working and staying at home can both be expressed as linear functions of the household characteristics, this expression could be written as:

$$
P(w o r k=1)=P\left(x^{\prime} B+z^{\prime} G+V^{\prime} H+u>0\right)
$$

In this equation, $\mathrm{V}$ is a binary variable that indicates whether there is domestic violence against the wife in the household.

Following the literature (Killingsworth and Heckman, 1986), the explanatory variable " $\mathrm{X}$ " is used to specify the likelihood of working and includes demographic variables - age, age squared, education, ethnicity - in order to capture the potential wages one can earn in the market. We also include controls for region-fixed effects to capture some of the regional differences in the job market by state. Also, as the job market is different between urban and rural areas, the estimations use the urban and rural samples separately. A set of variables Z - income level, work status of the husband are also included to capture additional information on household labor supply. Women in poor families or families where the husband is not working could show a higher probability to work. In addition, we also consider different variables that capture the incidence of domestic violence against 
women, which allows us to identify the effect of domestic violence on the wives' decisions to participate in the labor market.

This model is estimated using the entire sample, but it also considers samples differentiating the ethnicity of the wife and the area of residency. Considering that indigenous people are more "lenient" in terms of domestic violence, we argue that the incidence of violence has a different effect on employment because the perception of violence is different among these ethnic groups.

As stated in the introduction, the problem of estimating this original model is that the estimation of the coefficient could be biased and inconsistent due to endogeneity problems that could arise due to inverse causality issues, as is mentioned in the literature review. To address the problem of reverse causality, we propose an alternative approach using the changes in labor market status as the dependent variable. In this sense, restricting the sample to those households in which the women were working at some point during the year, our dependent variable is defined as a dummy that assumes the value of 1 if they left their jobs (or are not working) and 0 if they stayed working. Using this approach, we expect to address the simultaneity between violence and job decision, as the sample would mainly consist of women who were already working, women for whom the decision to work would have already been made. At the same time, one could expect that the change in job status does not have an effect on the general status of violence, assuming that the violence is an ongoing situation. In this sense, I propose a model to estimate the probability of women losing/leaving their jobs during the year conditional on the fact that they declared to be working at least once during the year. The specification that will be used is as follows:

$$
P(\text { Left } \text { work }=1 \mid \text { work year }=1)=P\left(x^{\prime} B+z^{\prime} G+\delta V+u>0\right)
$$

Although the information on the change of job status is available in this model, this is not the case for the change in incidence of violence. This lack of information could still be a source of endogeneity. To solve this problem, the alternative is to use an instrumental variable approach in 
order to create sufficient exogenous variation, which allows for identification of the effect of violence on the women's decisions to work.

In the first step, the presence of violence is estimated by applying a linear probability model (LPM) as suggested by Angrist and Kruger (1998), using the incidence of domestic violence in the area as an instrumental variable. This variable is defined as the ratio of households with domestic violence in relation to the total number of households in the nearby area. ${ }^{10}$ The assumption behind this variable implies that the effects from peers and social networks can create changes in household behaviors, such that households could face higher levels of violence if they are in neighborhoods with high levels of domestic violence. At the same time, there is an underlying assumption that the domestic violence incidence in the area does not affect women's decisions to work.

In the second step, the predictions of the first step this step are used to estimate the binary outcome model, using a probit model. The corresponding specification can be written as:

$$
\begin{aligned}
& P(\text { Left work }=1 \mid \text { work year }=1)=P\left(x^{\prime} B+z^{\prime} G+\delta \widehat{V}+u>0\right) \\
& V=x^{\prime} B+z^{\prime} G+\text { instrument }^{\prime} C+e
\end{aligned}
$$

An alternative methodology that can be used to address the endogeneity problem could be handling it as part of an unobserved heterogeneity. In this sense one can assume that certain kinds of women, due to cultural factors or experience, tend to get involved in marriages where the incidence of domestic violence is more likely. This approach implies that violence is a treatment that affects the decisions made by the victims. To introduce this feature, we allow for a different structure that accounts for the binary nature of the endogenous variable. Following Heckman (1978), we change the first stage of our model using a latent variable model. In the first stage, we initially estimate the

\footnotetext{
${ }^{10}$ For the construction of this variable, the geographical area is defined as the primary sample unit that was used for the construction of the survey.
} 
likelihood of being a victim of domestic violence. We then use the estimated mills ratio to correct the error term in the second stage.

For this approach, however, the second stage does not use a binary probit model; it uses a linear probability model (LPM) instead. The specification of this new model becomes:

$$
\begin{aligned}
& \text { Left work }=x^{\prime} B+z^{\prime} G+\delta V+r Z+e \\
& P\left(V=1 \mid W^{\prime} H\right)=P\left(W^{\prime} H+v>0\right)=\Phi\left(W^{\prime} H\right) \\
& r Z=\rho \sigma_{v}\left[\mathrm{~V} \frac{\phi\left(W^{\prime} H\right)}{1-\Phi\left(W^{\prime} H\right)}-(1-\mathrm{V}) \frac{\phi\left(W^{\prime} H\right)}{\Phi\left(W^{\prime} H\right)}\right]
\end{aligned}
$$

Assume that (e,v) follow a jointly normal distribution.

The set of variables $\mathrm{W}$ includes characteristics such as years of education, age when first married, and whether she is currently pregnant. To fulfill the identifying conditions, the vector W also includes additional characteristics that could affect the women's propensity to get attached to a violent relationship. These variables are: a) if she lived in a household where her father hit her mother, b) whether she accepts violence under certain conditions in a relationship, and c) the average incidence of domestic violence in the area where she lives. Once the model is estimated, the corresponding mills ratio is introduced in the second stage regression, which is estimated using a Linear Probability Model (LPM).

Under these considerations, the estimations of the proposed models are presented in the next section. With all the models, they only consider the sample of women who declared themselves to be working during the year.

\section{Empirical Results}

Following the existing literature, table 3 presents the results for our baseline model. We estimate the probability of women leaving their jobs (labor market exit), including a set of standard demographic variables such as family opportunity cost variables and controls for state fixed effects and other 
variables related to the husband's background, including the husband's work status, education and age. We also consider regional fixed effects and poverty levels in the region as proxies for labor demand. The first column of table 3 shows the base line results without considering any violence controls, while columns 2 to 4 include violence variables (total, physical and psychological respectively).

Table 3. Probit model: Probability of leaving the Job, marginal effects

\begin{tabular}{|c|c|c|c|c|}
\hline VARIABLES & (1) & (2) & (3) & (4) \\
\hline Age & $\begin{array}{c}-0.0192 * * * \\
(0.00433)\end{array}$ & $\begin{array}{c}-0.0194 * * * \\
(0.00435)\end{array}$ & $\begin{array}{c}-0.0194 * * * \\
(0.00434)\end{array}$ & $\begin{array}{c}-0.0193 * * * \\
(0.00434)\end{array}$ \\
\hline Years of education & $\begin{array}{l}0.000501 \\
(0.00153)\end{array}$ & $\begin{array}{l}0.000626 \\
(0.00154)\end{array}$ & $\begin{array}{l}0.000608 \\
(0.00154)\end{array}$ & $\begin{array}{l}0.000603 \\
(0.00154)\end{array}$ \\
\hline Currently Pregnant & $\begin{array}{c}0.0631 * * * \\
(0.0206)\end{array}$ & $\begin{array}{c}0.0654 * * * \\
(0.0209)\end{array}$ & $\begin{array}{c}0.0650^{* * *} \\
(0.0208)\end{array}$ & $\begin{array}{c}0.0661 * * * \\
(0.0210)\end{array}$ \\
\hline Children 6 years or older & $\begin{array}{c}0.00563^{*} \\
(0.00297)\end{array}$ & $\begin{array}{l}0.00509 * \\
(0.00294)\end{array}$ & $\begin{array}{c}0.00519 * \\
(0.00298)\end{array}$ & $\begin{array}{c}0.00515^{*} \\
(0.00295)\end{array}$ \\
\hline Children 5 years or younger & $\begin{array}{c}0.00206 \\
(0.00566)\end{array}$ & $\begin{array}{c}0.00203 \\
(0.00570)\end{array}$ & $\begin{array}{c}0.00195 \\
(0.00568)\end{array}$ & $\begin{array}{c}0.00196 \\
(0.00568)\end{array}$ \\
\hline Age at first marriage & $\begin{array}{c}0.00126 \\
(0.00115)\end{array}$ & $\begin{array}{c}0.00145 \\
(0.00115)\end{array}$ & $\begin{array}{c}0.00140 \\
(0.00115)\end{array}$ & $\begin{array}{c}0.00144 \\
(0.00114)\end{array}$ \\
\hline Violence & & $\begin{array}{c}0.0249 * * * \\
(0.00844)\end{array}$ & & \\
\hline Physical Violence & & & $\begin{array}{c}0.0167 * * \\
(0.00792)\end{array}$ & \\
\hline Psychological Violence & & & & $\begin{array}{c}0.0215^{* * *} \\
(0.00810)\end{array}$ \\
\hline Observations & 7,095 & 7,095 & 7,095 & 7,095 \\
\hline
\end{tabular}

The controls included are the standard found in violence-labor market literature, and behaved as would be intuitively expected. Age is negatively related to labor market exiting, which goes in line with the job stability evidence found in Landa (2006). We find an insignificant positive effect of years of education, a result that may be implying that job mobility is higher for higher-educated workers, which is in line with the empirical evidence found for Bolivia in Canavire-Bacarreza (2009). Interestingly, we find that pregnancy has a highly positive and significant coefficient, which might indicate that either there is a certain level of discrimination towards pregnant women (Lai and 
Stanley 2005), or that women decide to leave their jobs in the short run due to their pregnancy (maternity leave). The number of children in the households also has a positive relationship (although not highly significant) with labor market exiting; this is intuitively appealing since having more children creates more household dependence for the female population and therefore working/leisure time decreases.

Our results upon examining the effects of domestic violence on labor market exiting confirm the hypothesis found in the literature: that domestic violence (both physical and psychological) increases the probability of women exiting labor markets. We also find that psychological violence increases the probability of leaving a job by 1 percent more compared to physical violence. This result goes in line with the psychological findings (see O'Leary 1999), which emphasizes that psychological domestic violence has a greater adverse effect on working women than physical abuse in terms of job performance.

Considering that labor markets are different in urban and rural areas and for indigenous and nonindigenous populations, we estimate the same baseline model for both areas and both ethnic groups. We present the initial results and complement the analysis with our instrumental variables ${ }^{11}$ and treatment selection regressions. ${ }^{12}$

As Table 4 shows, the probability of leaving the job is higher for women in urban areas and highly significant compared to rural areas (except when using our instrument); this result corresponds to the hypothesis that the dynamics of job creation and destruction in the labor market occurs much more swiftly in the urban labor market than in the rural market.

\footnotetext{
${ }^{11}$ For the instrumental variable approach, the Wald exogeneity test is not significant, indicating that our instrument is exogenous in the analysis, for this sample. The first step regression also showed that the instrument is highly significant and correlated with domestic violence.

12 As it can be seen in Appendix 2 table 6, all the variables included as exclusion restrictions: regional violence, intergenerational violence, acceptance of violence and age at first marriage squared, are statistically significant.
} 
Table 4. Probit Model: Probability of leaving the Job by area and ethnicity, marginal effects

\begin{tabular}{|c|c|c|c|c|c|c|}
\hline VARIABLES & Probit & $\begin{array}{c}\text { Urban } \\
\text { IV neighbor }\end{array}$ & Selection & Probit & $\begin{array}{c}\text { Rural } \\
\text { IV } \\
\text { neighbor } \\
\end{array}$ & Selection \\
\hline \multirow[t]{3}{*}{ Violence } & $\begin{array}{c}0.0269 * * \\
(0.012)\end{array}$ & $\begin{array}{l}0.0487 \\
(0.037) \\
\end{array}$ & $\begin{array}{c}0.0666^{*} \\
(0.034)\end{array}$ & $\begin{array}{c}0.0173^{*} \\
(0.010) \\
\end{array}$ & $\begin{array}{c}0.0446^{*} \\
(0.024) \\
\end{array}$ & $\begin{array}{c}0.0484 * * \\
(0.023) \\
\end{array}$ \\
\hline & \multicolumn{3}{|c|}{ Indigena } & \multicolumn{3}{|c|}{ No indigena } \\
\hline & Probit & IV neighbor & Selection & Probit & $\begin{array}{c}\text { IV } \\
\text { neighbor }\end{array}$ & Selection \\
\hline Violence & $\begin{array}{c}0.00969 \\
(0.010)\end{array}$ & $\begin{array}{l}0.0405 \\
(0.030)\end{array}$ & $\begin{array}{c}0.037 \\
(0.028)\end{array}$ & $\begin{array}{c}0.0390 * * * \\
(0.012)\end{array}$ & $\begin{array}{c}0.0545^{*} \\
(0.036)\end{array}$ & $\begin{array}{c}0.0778^{* *} \\
(0.034)\end{array}$ \\
\hline
\end{tabular}

Table 4 also shows that non-indigenous populations have higher probabilities of leaving the job in the presence of violence (physical and psychological), while indigenous populations do not show any significant effect of violence on job exit, although the estimation signs are still positive. These results indicate that if indigenous women are working, the incidence of violence would have almost no effect on their decisions to leave their jobs. Perhaps this evidence also indicates that indigenous people are usually less affected by intra-household violence because they see it as a "normal" outcome of marriage. In summation, this compelling evidence is in line with our initial argument that indigenous women are more accepting of domestic violence and do not change their behavior because of it, while non-indigenous women are more responsive to domestic violence.

Given that there is a high correlation between education, incomes and the differences between indigenous and non-indigenous population, we would expect the effects to differ along the income distribution.

As was presented before, Table 5 presents the results for the effect of violence on labor market exit along the income distribution, and except for the second quintile, the results are mostly insignificant. This initial result leads us to think that there could also be some heterogeneous impacts along the distribution of income; therefore, we proceed to examine the effects of violence on non-indigenous 
and indigenous populations. Looking at the differentiated effects for indigenous and non-indigenous populations, we find interesting results.

Poor indigenous populations (Quintiles 1 to 3) present an insignificant effect of violence, while richer ones have a positive and highly significant effect. For non-indigenous populations, we find the opposite: Poor segments of the population (Q1 to Q3) show significant and positive effects, while richer segments (Q4 and Q5) have extremely small and non-significant effects.

These results support our argument that there are two different stories driving the effects of domestic violence and their correlation with the education and income characteristics of people. On the indigenous side, people at the highest quintiles receive better education and become more aware of what domestic violence is, becoming more responsive to violence. On the non-indigenous side, people in the middle, middle-lower and lower quintiles are more responsive to violence because they do not consider domestic violence to be normal. This might translate into their decisions being more sensitive to violence. The small and insignificant effects on higher quintiles of non-indigenous populations can mainly be explained by the lower intensity of violence in this group. ${ }^{13}$ It could also be the case that in households where violence was already affecting the marriage, the couple divorced (Bowlus and Saitz, 2006). The remaining sample (the one we observe) is composed of the less-responsive ones.

\footnotetext{
13 While $49.35 \%$ of indigenous women in the highest quintile declared to have suffered from some kind of physical domestic violence frequently, this ratio is much lower among non-ingenuous women (36.89\%). The situation is similar considering only psychological violence. The incidence of frequent Psychological violence is $33.91 \%$ for non-indigenous women of the highest quintile, compared to $43.29 \%$ for indigenous women.
} 
Table 5. Probability of leaving the Job by ethnicity and income, marginal effects

\begin{tabular}{|c|c|c|c|c|c|c|c|c|c|c|c|c|c|c|c|}
\hline & \multicolumn{3}{|c|}{$\begin{array}{c}\text { Q1 } \\
\text { Full Sample }\end{array}$} & \multicolumn{3}{|c|}{$\begin{array}{c}\text { Q2 } \\
\text { Full Sample }\end{array}$} & \multicolumn{3}{|c|}{$\begin{array}{c}\text { Q3 } \\
\text { Full Sample }\end{array}$} & \multicolumn{3}{|c|}{$\begin{array}{c}\text { Q4 } \\
\text { Full Sample }\end{array}$} & \multicolumn{3}{|c|}{$\begin{array}{c}\text { Q5 } \\
\text { Full Sample }\end{array}$} \\
\hline & Probit & IV & Selec & Probit & IV & Selec & Probit & IV & Selec & Probit & IV & Selec & Probit & IV & Selec \\
\hline \multirow[t]{3}{*}{ Violence } & $\begin{array}{l}0.0144 \\
(0.014)\end{array}$ & & & $\begin{array}{c}0.0399 * * * \\
(0.012)\end{array}$ & & & $\begin{array}{c}0.011 \\
(0.028)\end{array}$ & & & $\begin{array}{c}0.0258 \\
(0.02)\end{array}$ & & & $\begin{array}{c}0.011 \\
(0.017)\end{array}$ & & \\
\hline & & $\begin{array}{c}\text { Q1 } \\
\text { ndigenas }\end{array}$ & & & $\begin{array}{l}\text { Q2 } \\
\text { digenas }\end{array}$ & & & $\begin{array}{c}\text { Q3 } \\
\text { Indigena }\end{array}$ & & & & $\begin{array}{r}Q \\
\text { Ind }\end{array}$ & $\begin{array}{l}-\mathrm{Q} 5 \\
\text { genas }\end{array}$ & & \\
\hline & Probit & IV & Selec & Probit & IV & Selec & Probit & IV & Selec & & & I & & Selc & tion \\
\hline \multirow[t]{3}{*}{ Violence } & $\begin{array}{c}-0.0032 \\
(0.02) \\
\end{array}$ & $\begin{array}{c}0.00382 \\
(0.033) \\
\end{array}$ & $\begin{array}{l}0.0213 \\
(0.027) \\
\end{array}$ & $\begin{array}{l}0.0163 \\
(0.012) \\
\end{array}$ & $\begin{array}{l}0.0358 \\
(0.029) \\
\end{array}$ & $\begin{array}{l}0.0235 \\
(0.049) \\
\end{array}$ & $\begin{array}{c}-0.0395 \\
(0.03) \\
\end{array}$ & $\begin{array}{l}0.0771 \\
(0.099) \\
\end{array}$ & $\begin{array}{l}0.0223 \\
(0.089) \\
\end{array}$ & $\begin{array}{r}0.0 \\
(0 .\end{array}$ & $\begin{array}{l}1 * * \\
22) \\
\end{array}$ & $\begin{array}{l}0.0 \\
(0 .\end{array}$ & $\begin{array}{l}886 \\
87)\end{array}$ & & \\
\hline & \multicolumn{6}{|c|}{$\begin{array}{c}\text { Q1-Q2 } \\
\text { Non-Indigenous }\end{array}$} & \multicolumn{3}{|c|}{$\begin{array}{c}\text { Q3 } \\
\text { Non-Indigenous }\end{array}$} & \multicolumn{3}{|c|}{$\begin{array}{c}\text { Q4 } \\
\text { Non-Indigenous }\end{array}$} & \multicolumn{3}{|c|}{$\begin{array}{c}\text { Q5 } \\
\text { Non-Indigenous }\end{array}$} \\
\hline & \multicolumn{2}{|c|}{ Probit } & \multicolumn{2}{|c|}{ IV } & \multicolumn{2}{|c|}{ Selec } & Probit & IV & Selec & Probit & IV & Selec & Probit & IV & Selec \\
\hline Violence & \multicolumn{2}{|c|}{$\begin{array}{c}0.0932^{* * *} \\
(0.019)\end{array}$} & \multicolumn{2}{|c|}{$\begin{array}{c}0.136^{* * *} \\
(0.047)\end{array}$} & \multicolumn{2}{|c|}{$\begin{array}{c}0.169^{* * *} \\
(0.055)\end{array}$} & $\begin{array}{c}0.064^{*} \\
(0.03)\end{array}$ & $\begin{array}{l}0.0978 \\
(0.094)\end{array}$ & $\begin{array}{r}0.161^{* *} \\
(0.080)\end{array}$ & $\begin{array}{l}0.016 \\
(0.03)\end{array}$ & $\begin{array}{l}0.0811 \\
(0.060)\end{array}$ & $\begin{array}{r}0.056 \\
(0.062)\end{array}$ & $\begin{array}{l}0.001 \\
(0.01)\end{array}$ & $\begin{array}{l}-0.0326 \\
(0.053)\end{array}$ & $\begin{array}{r}-0.0188 \\
(0.081)\end{array}$ \\
\hline
\end{tabular}

Notes: Similar covariates as in table 3, geographic, regional poverty, income and husband related variables are included. For Indigenous population

we merge Q4 and Q5 due to small sample problems. Similarly for Non-Indigenous populations Q1 and Q2 are merged.

Full results for the simple probit can be found in the Appendix A2, Tables 3, 4 and 5

Corrections using instrumental variables and treatment selection are in Tables 9 and 10

Robust standard errors in parentheses

$* * * \mathrm{p}<0.01, * * \mathrm{p}<0.05, * \mathrm{p}<0$ 


\subsection{Robustness of the estimation: What explains the differences?}

As we addressed in the previous section, indigenous peoples have a smaller response to violence than non-indigenous people. The following step is to identify which factors could better explain this behavior. In Table 6, we present probit models using different subgroups and concepts, attempting to search for an explanation.

Our first hypothesis is related to acceptance. If women accept violence as normal behavior, we would expect that they would be less responsive than women who do not accept violence.

Using self-declared information on their perceptions of domestic violence, we find that women who accept violence are even more responsive to domestic violence. Among non-indigenous people, for instance, the marginal effect was 0.0861 if they accept violence compared to 0.0261 if they do not. Although a similar pattern can be seen for indigenous women, domestic violence is not significant in either case.

One characteristic of indigenous women is that they are, in general, less educated than nonindigenous women. If we compare women with similar levels of education, they could possibly have similar responsive behaviors. When considering less educated women (those with less than 5 years of education), we find that non-indigenous women are more responsive than average (0.0559), while indigenous women with the same level of education show no significant difference. In the case of women with average levels of education (6 to 11 years), both groups of women show relatively high and significant responsiveness to violence, although it is still higher among non-indigenous people. No significant effects are seen for people with 12 years of education or more.

The civil status of women could also affect the differences in their reactions to violence. People who are married might have weaker reactions than people who are "living together," because they are tied together with a stronger commitment. This stronger commitment could make certain threats (being abandoned, for example) less credible. We find that people who are living together have a strong 
and more significant response to violence compared to people who are married. Domestic violence, however, still shows no significant effect on indigenous women.

An alternative to analysis is that instead of analyzing differences of the women's characteristics, we try to consider the differences in the nature of violence against women. The first factor being consider is intensity.

Using each variable of physical and psychological violence described in the appendix 1, we create an index giving an equal weight to each source of violence ${ }^{14}$. This index is transformed into dummy variables indicating if the women answered passively in at least 1, 2, 3 and 4 variables ${ }^{15 .}$ We find that only being a victim (at least one positive answer) seems to be the most important factor when considering domestic violence, since further dummies remain no significant. For indigenous women, none of the dummies were shown to be significant. Nevertheless, one should notice the coefficients are not small for all the cases.

In the survey, besides considering information on domestic violence, information is also provided on whether or not women declared that someone else physically hurt her, besides her husband. Including this as an explanatory variable shows that it seems to have an even stronger effect on a women's decision of leaving the market. We still observe that indigenous women are less responsive to both kinds of violence than non-indigenous women are.

\footnotetext{
14 The index is the sum of positive responses to domestic examples given during the survey interview, eg. If a woman answers positively in three questions, the index take value of 3 .

15 The index goes up to 10 , but only the first 4 were used in the regression.
} 
Table 6. Robustness test and different specifications

\begin{tabular}{|c|c|c|c|}
\hline & Entire Sample & Indigenous & Non indigenous \\
\hline Base line Probit model & $\begin{array}{c}0.0249 * * * \\
(0.008)\end{array}$ & $\begin{array}{c}0.00969 \\
(0.010)\end{array}$ & $\begin{array}{c}0.0390 * * * \\
(0.012)\end{array}$ \\
\hline \multicolumn{4}{|l|}{ Acceptance of violence } \\
\hline Accepts & $\begin{array}{c}0.0460^{* * *} \\
(0.0154)\end{array}$ & $\begin{array}{c}0.0197 \\
(0.0145)\end{array}$ & $\begin{array}{c}0.0861 * * * \\
(0.0234)\end{array}$ \\
\hline Do not accept & $\begin{array}{c}0.0176^{*} \\
(0.00949)\end{array}$ & $\begin{array}{l}0.00734 \\
(0.0115)\end{array}$ & $\begin{array}{c}0.0261 * * \\
(0.0130)\end{array}$ \\
\hline \multicolumn{4}{|l|}{ Education } \\
\hline Less than 5 years of education & $\begin{array}{c}0.00994 \\
(0.00991)\end{array}$ & $\begin{array}{c}-0.00432 \\
(0.0107)\end{array}$ & $\begin{array}{c}0.0559 * * * \\
(0.0196)\end{array}$ \\
\hline \multicolumn{4}{|l|}{ Between 6 and 11 years of } \\
\hline education & $\begin{array}{c}0.0780 * * * \\
(0.0193)\end{array}$ & $\begin{array}{c}0.0506^{* * *} \\
(0.0174)\end{array}$ & $\begin{array}{c}0.0834 * * * \\
(0.0225)\end{array}$ \\
\hline 12 years of education & $\begin{array}{c}-0.00360 \\
(0.0251)\end{array}$ & $\begin{array}{c}0.0170 \\
(0.0487)\end{array}$ & $\begin{array}{c}-0.00223 \\
(0.0244)\end{array}$ \\
\hline 13 or more years of education & $\begin{array}{l}0.00907 \\
(0.0227)\end{array}$ & & $\begin{array}{l}0.00614 \\
(0.0237)\end{array}$ \\
\hline \multicolumn{4}{|l|}{ Civil Status } \\
\hline Married & $\begin{array}{c}0.0122 \\
(0.00893)\end{array}$ & $\begin{array}{l}0.00761 \\
(0.0106)\end{array}$ & $\begin{array}{c}0.0183 \\
(0.0142)\end{array}$ \\
\hline Living together & $\begin{array}{c}0.0566^{* *} \\
(0.0226)\end{array}$ & $\begin{array}{c}0.0135 \\
(0.0271)\end{array}$ & $\begin{array}{c}0.0857 * * * \\
(0.0247)\end{array}$ \\
\hline \multicolumn{4}{|l|}{ Violence intensity (up to 10 ) } \\
\hline Possitive on at least 1 & $\begin{array}{c}0.0328^{* *} \\
(0.0132)\end{array}$ & $\begin{array}{c}0.0216 \\
(0.0145)\end{array}$ & $\begin{array}{c}0.0440 * * \\
(0.0201)\end{array}$ \\
\hline Possitive on at least 2 & $\begin{array}{l}-0.0127 \\
(0.0154)\end{array}$ & $\begin{array}{l}-0.0314 \\
(0.0234)\end{array}$ & $\begin{array}{c}0.000802 \\
(0.0246)\end{array}$ \\
\hline Possitive on at least 3 & $\begin{array}{l}0.00985 \\
(0.0202)\end{array}$ & $\begin{array}{c}0.0283 \\
(0.0305)\end{array}$ & $\begin{array}{c}-0.00448 \\
(0.0265)\end{array}$ \\
\hline Possitive on at least 4 & $\begin{array}{c}-0.00856 \\
(0.0165)\end{array}$ & $\begin{array}{l}-0.0111 \\
(0.0218)\end{array}$ & $\begin{array}{c}-0.00558 \\
(0.0245)\end{array}$ \\
\hline \multicolumn{4}{|l|}{ Someone else hurt her } \\
\hline Violence & $\begin{array}{c}0.0238^{* * *} \\
(0.00847)\end{array}$ & $\begin{array}{l}0.00875 \\
(0.0103)\end{array}$ & $\begin{array}{c}0.0379 * * * \\
(0.0122)\end{array}$ \\
\hline Other person & $\begin{array}{c}0.0378^{* *} \\
(0.0177)\end{array}$ & $\begin{array}{c}0.0207 \\
(0.0207)\end{array}$ & $\begin{array}{c}0.0553 * * \\
(0.0244)\end{array}$ \\
\hline \multicolumn{4}{|l|}{ Violence under drugs or alcohol } \\
\hline Violence & $\begin{array}{l}0.0236 * * \\
(0.00953)\end{array}$ & $\begin{array}{l}0.0200^{*} \\
(0.0117)\end{array}$ & $\begin{array}{c}0.0292 * * \\
(0.0139)\end{array}$ \\
\hline Under Drugs or Alcohol & $\begin{array}{l}0.00330 \\
(0.0110)\end{array}$ & $\begin{array}{c}-0.0210^{*} \\
(0.0115)\end{array}$ & $\begin{array}{c}0.0268 \\
(0.0182)\end{array}$ \\
\hline Without considering D A violence & $\begin{array}{c}0.0265^{* * *} \\
(0.0100)\end{array}$ & $\begin{array}{l}0.0240^{*} \\
(0.0129)\end{array}$ & $\begin{array}{c}0.0280 * * \\
(0.0137)\end{array}$ \\
\hline Only considering D A violence & $\begin{array}{l}0.00122 \\
(0.0117)\end{array}$ & $\begin{array}{c}-0.0238^{* *} * \\
(0.0121)\end{array}$ & $\begin{array}{c}0.0254 \\
(0.0189)\end{array}$ \\
\hline
\end{tabular}

All regressions follow the base line probit specification

Robust standard errors in parentheses *** $\mathrm{p}<0.01, * * \mathrm{p}<0.05, * \mathrm{p}<0$.

Finally, we try to differentiate the circumstances of when the husband hurt their wives. Specifically, we use information about when women declared that their husband was under the influence of alcohol or drugs when he hit her, and use it as an additional explanatory variable in the specification. 
The results here are unexpected. For non-indigenous women, domestic violence alone has a relatively smaller effect than in the baseline model, and although violence under alcohol is not significant, its coefficient has a similar magnitude. More surprising is the effect of this variable for the indigenous women specification. On the one hand, violence itself becomes significant $(0.02$ marginal effect), which is now comparable to the marginal effect of domestic violence of nonindigenous women. On the other hand, domestic violence under the effect of alcohol is significant, but with a negative coefficient, meaning that this kind of violence reduces the probability of leaving the job market.

Trying to exploit these findings further, we estimate two additional models for subsamples where: women who suffered from violence under drugs or alcohol are excluded, and where women who suffer domestic violence not under the influence of alcohol or drugs are excluded. In the first case, we find that domestic violence has a significant and positive effect on the probability of leaving the job market for both indigenous and non-indigenous women, with similar marginal effects $(0.024$ and 0.028 respectively).

In the second, domestic violence under the effects of alcohol or drugs alone seems to have no effect among non-indigenous women, but has a negative and significant effect for indigenous women (-.0238).

\section{Conclusions}

In this paper, we presented evidence in order to analyze the heterogeneous effects of violence on the exit from the labor market of women in a developing country. The analysis started by modeling the effect of different factors, generally considered in the literature, on female labor force participation. This found that all variables present the expected coefficients. In the next step of the analysis, we included three different types of domestic violence in the estimations — physical, psychological and the combination of both — finding a positive and significant correlation between job exit and 
violence, after controlling for other covariates. This indicates that there is a dominating positive correlation between domestic violence and women's exit from labor market.

After using different methodologies to address possible problems of endogeneity, we found that our results are robust across the different specifications, and, if anything, our estimations are understating the effects of domestic violence.

In respect to the cultural differences between indigenous and non-indigenous people, we found that there is indeed a differentiated effect between these two groups. Specifically, we found that indigenous women are in general less responsive to domestic violence, except for higher income groups. We also found that non-indigenous women of middle and lower income are much more responsive to violence.

Analyzing different hypothesis that can explain the differentiated effect of domestic violence on the labor market status, we find that our results are robust across alternative measures of violence and for specific subsamples of education, acceptance and marital status. We find, however, that the difference in the response greatly reduces when we exclude the observations when the husband has problems with alcohol or drugs.

Some issues remain for further research. First, it is possible that women can also decide to terminate their marriages instead of leaving their jobs, particularly women with high education levels and income. This possibility should be taken into consideration in further research to analyze if it changes the conclusions obtained in this paper. Second, the present analysis focused on women's decisions to leave their jobs; however, it might be interesting to analyze what the effects would be on the actual decision of entering in the job market subject and the incidence of domestic violence. Third, although women are the main victims of violence, one could also analyze if there is any effect on men's labor status when they are the victims. 


\section{References}

Aizer, Anna,Wages, (2007) "Violence and Health in the Household" NBER Working Paper No. W13494.

Albo, X and Molina R. (2006). "Gama étnica y lingüística de la población boliviana” UNDP. La Paz - Bolivia

Albo, Xavier. (1994) "Ethnic Violence: The Case of Bolivia." In K. Rupesinghe and M. Rubio C. The Culture of Violence. New York. United Nations University Press.

Angrist, J. D. \& Krueger, A. B. (2000). Instrumental variables and the search for identification: From supply and demand to natural experiments. The Journal of Economic Perspectives, 15, 69-85.

Becker, Gary S., "A Theory of the Allocation of Time," Economic Journal, Vol. 75, No. 299, (September 1965), 493-517.

Bhattacharya, M, Bedi, A. and Chhachhi, A (2009). "Marital Violence and Women's Employment and property status: Evidence from Indian Villages" IZA working paper 4361

Bowlus, A. and Seitz, S (1998). "The Role of Domestic Abuse in Labor and Marriage Markets". Working paper.

Bowlus, A. and Seitz, S (2006). "Domestic Violence, Employment and Divorce". International Economic Review, vol 47, No 4

Canavire-Bacarreza, Gustavo (2009) "Urban Labor Markets and Skills in Bolivia, a diagnostic" World Bank Background paper. Mimeograph

Ellsberg, M., Heise, L., Pena, R., Agurto, S. and Winkvist A (2001). "Researching Domestic Violence Against Women: Methodological and Ethical Considerations." Studies in Family Planning, 32(1).

Franzway, S. (1998) 'Sexual Politics in Labour Movements', paper to the 14th World Congress of Sociology, Montreal, 26 July-1 August.

Gelles, R (1976) “Abused: why do they Stay?". Journal of marriage and the Family. Vol 38 No 4

Heckman, James J. (1978) "Dummy Endogenous Variables in Simultaneous Equation System", Econometrica, Vol 46, No 4

Instituto Nacional de Estadistica (2003). "Informe de la Encuesta Nacional de Salud 2003" Bolivia

INE-UNICEF (2007). "Violencia contra la Ninez en Bolivia”, La Paz-Bolivia

Kalmuss, D., \& Straus, M. (1990). Wife's marital depen-dency and wife abuse. In M. Straus \& R. Gelles (Eds.), Physical violence in American families (pp. 369-382). New Brunswick: Transaction Publishers.

Killingsworth, Mark and James Heckman. "Labor Supply of Women: A Survey" in Orley Ashenfelter and Richard Layard (eds), Handbook of Labor Economics, North Holland, Amsterdam , 1986.

Lai, Yu-Cheng and Masters, Stanley (2005) "The Effects of Mandatory Maternity and Pregnancy Benefits on Women's Wages and Employment in Taiwan, 1984-1996," Industrial \& Labor Relations Review, Vol. 58, No. 2, article 6.

Landa, Fernando (2006). "Elecciones de mercado de trabajo en la población ocupada. ¿Es realmente malo ser informal?”. Mimeo.

Lloyd, S (1997) “The effects of Domestic Violence on Women's Employtment" Law and Policy, Vol 19 No 2

Lloyd, S. and Taluc, N. (1999) "Effects of Male Violence on Female Employment" Violence against women. Vol 5 No 4

Machicado, Jorge, (2010) "¿Que es la Justicia comunitaria ?", http://jorgemachicado.blogspot.com/2009/01/justicia-comunitaria.html 
Macmillan, R. and Gartner R. (1999). "When She Brings Home the Bacon: Labor Force Participation and the Risk of Spousal Violence Against Women." Journal of Marriage and the Family. 61

Meisel, J., Chandler, D., \& Menees Rienzi, B. (2003). Domestic violence prevalence and effects on employment in two California TANF populations. Violence Against Women, 9, 1191-1212.

Molm, L. (1989) "Punishment Power: A balancing process in Power Dependence Relations" American Journal of Sociology. Vol 94 No 6

Molm, L. (1997). Risk and power use: Constraints on the use of coercion in exchange. American Sociologi-cal Review, 62, 113-133.

O'Leary, K. D. (1999). "Psychological Abuse: A Variable Deserving Critical Attention in Domestic Violence." Violence and Victims 14: 3-23.

Shannon N. Seitz, 1999. "Labor Supply, Divorce and Remarriage," UWO Department of Economics Working Papers 9902, University of Western Ontario, Department of Economics

Swanberg Jennifer E. and T. K. Logan (2005), "Domestic Violence and Employment: A Qualitative Study" Journal of Occupational Health Psychology, 2005, Vol. 10, No. 1, 3-17

Tauchen, H. , Witte, A. and Long S. (1991) "Violence in the Family: A non-random Affair", International Economics Review. Vol 32, No 2

Tauchen, H. , Witte, A. (1995) "The dynamics of domestic Violence". American Economic Review. Vol 85 No 2

Tolman R. and Wang, H. (2005) “Domestic Violence and Women's Employment: Fixed effects Models of three waves of Women's Employment Study Data" American Journal of Comunnity Psychology Vol 36 No 12

UDAPE-UNICEF (2008a). "Bolivia Determinantes de la Violencia contra la Niñez y Adolescencia". La Paz - Bolivia.

UDAPE-UNICEF (2008b). "La respuesta institucional del Estado a la temática de violencia contra la niñez y adolescencia". La Paz Bolivia

WHO (2002) World report on violence and heath. Geneva: WHO 


\section{Appendix 1 Variable definitions}

\begin{tabular}{|c|c|}
\hline Variables & Definition \\
\hline Age & Age of wife in years \\
\hline Age Square & Age square of wife in years \\
\hline Education in years & Years of educations \\
\hline Income & Income index 1 (poorest) to 5 (richest) \\
\hline Indigenous $=1$ & 1 if indigenous, identified by language spoken during childhood \\
\hline No of Children older than 5 & Number of own children older than 5 years old \\
\hline No of Children younger than 5 & Number of own children born in the last 5 years \\
\hline Worked during the year & 1 if wife declare to have worked in the last year \\
\hline Currently working & 1 if wife declare to be working \\
\hline Husband works & 1 if husband works in the labor market \\
\hline Husband Age & Husband age in years \\
\hline Husband Education & Husband education in years \\
\hline Physical Violence & $\begin{array}{l}1 \text { if women declared to have suffered frequently or some times on } \\
\text { the following situations }\end{array}$ \\
\hline \multirow{7}{*}{ Psyco. Violence } & $\begin{array}{ll}\text { - } & \text { Spouse ever pushed you } \\
\text { - } & \text { spouse ever hit you with his hand/foot } \\
\text { - } & \text { spouse ever hit you with something harmful } \\
\text { - } & \text { spouse ever tried to strangle you } \\
\text { - } & \text { spouse ever forced you to have sex }\end{array}$ \\
\hline & $\begin{array}{l}1 \text { if women declared to have suffered frequently or some times on } \\
\text { the following situations }\end{array}$ \\
\hline & - husband accuses her of unfaithfulness \\
\hline & - $\quad$ husband tried to limit her contact with family \\
\hline & - $\quad$ husband tells you "you are good for nothing" \\
\hline & - husband threatened you with "he will leave the house" \\
\hline & $\begin{array}{l}\text { - } \quad \begin{array}{l}\text { husband tells you "he would not give you economical } \\
\text { support" }\end{array}\end{array}$ \\
\hline Urban Area & 1 if wife lives in the urban areas \\
\hline Wife Violence acceptance & 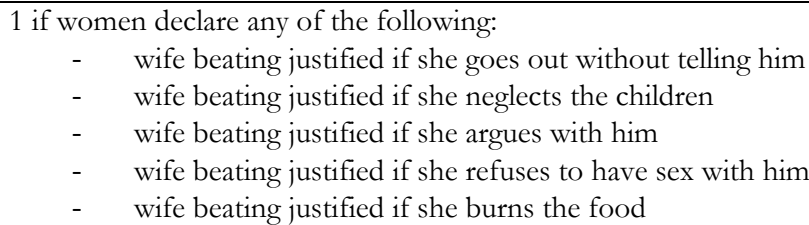 \\
\hline Intergenerational Violence & $\begin{array}{l}1 \text { if women answer positive to: } \\
-\quad \text { did your father ever beat your mother? }\end{array}$ \\
\hline
\end{tabular}




\section{Appendix 2}

Table A2.1 Determinants of Job exit, Probit Model Marginal effects

\begin{tabular}{|c|c|c|c|c|}
\hline VARIABLES & $(1)$ & $(2)$ & (3) & (4) \\
\hline Age & $\begin{array}{c}-0.0192^{* * *} \\
(0.00433)\end{array}$ & $\begin{array}{c}-0.0194 * * * \\
(0.00435)\end{array}$ & $\begin{array}{c}-0.0194 * * * \\
(0.00434)\end{array}$ & $\begin{array}{c}-0.0193 * * * \\
(0.00434)\end{array}$ \\
\hline Age Squared & $\begin{array}{c}0.000193^{* * *} \\
(6.39 \mathrm{e}-05)\end{array}$ & $\begin{array}{c}0.000196 * * * \\
(6.40 \mathrm{e}-05)\end{array}$ & $\begin{array}{c}0.000196^{* * *} \\
(6.40 \mathrm{e}-05)\end{array}$ & $\begin{array}{c}0.000194 * * * \\
(6.39 \mathrm{e}-05)\end{array}$ \\
\hline Years of education & $\begin{array}{l}0.000501 \\
(0.00153)\end{array}$ & $\begin{array}{l}0.000626 \\
(0.00154)\end{array}$ & $\begin{array}{l}0.000608 \\
(0.00154)\end{array}$ & $\begin{array}{l}0.000603 \\
(0.00154)\end{array}$ \\
\hline Currently Pregnant & $\begin{array}{c}0.0631 * * * \\
(0.0206)\end{array}$ & $\begin{array}{c}0.0654^{* * *} \\
(0.0209)\end{array}$ & $\begin{array}{c}0.0650^{* * * *} \\
(0.0208)\end{array}$ & $\begin{array}{c}0.0661 * * * \\
(0.0210)\end{array}$ \\
\hline Income $\mathrm{Q}=2$ & $\begin{array}{c}0.0126 \\
(0.0163)\end{array}$ & $\begin{array}{c}0.0106 \\
(0.0161)\end{array}$ & $\begin{array}{c}0.0112 \\
(0.0162)\end{array}$ & $\begin{array}{c}0.0111 \\
(0.0162)\end{array}$ \\
\hline Income $\mathrm{Q}=3$ & $\begin{array}{c}0.0519 * * \\
(0.0236)\end{array}$ & $\begin{array}{c}0.0507 * * \\
(0.0234)\end{array}$ & $\begin{array}{c}0.0510^{* *} \\
(0.0235)\end{array}$ & $\begin{array}{c}0.0511^{* *} \\
(0.0234)\end{array}$ \\
\hline Income $\mathrm{Q}=4$ & $\begin{array}{c}0.0205 \\
(0.0219)\end{array}$ & $\begin{array}{c}0.0191 \\
(0.0217)\end{array}$ & $\begin{array}{c}0.0192 \\
(0.0217)\end{array}$ & $\begin{array}{c}0.0192 \\
(0.0217)\end{array}$ \\
\hline Income $\mathrm{Q}=5$ & $\begin{array}{c}0.0154 \\
(0.0245)\end{array}$ & $\begin{array}{c}0.0158 \\
(0.0243)\end{array}$ & $\begin{array}{c}0.0158 \\
(0.0243)\end{array}$ & $\begin{array}{c}0.0153 \\
(0.0243)\end{array}$ \\
\hline No of Children 6 years or older & $\begin{array}{l}0.00563 * \\
(0.00297)\end{array}$ & $\begin{array}{l}0.00509 * \\
(0.00294)\end{array}$ & $\begin{array}{l}0.00519 * \\
(0.00298)\end{array}$ & $\begin{array}{l}0.00515^{*} \\
(0.00295)\end{array}$ \\
\hline No of Children 5 years or younger & $\begin{array}{c}0.00206 \\
(0.00566)\end{array}$ & $\begin{array}{c}0.00203 \\
(0.00570)\end{array}$ & $\begin{array}{c}0.00195 \\
(0.00568)\end{array}$ & $\begin{array}{c}0.00196 \\
(0.00568)\end{array}$ \\
\hline Region 2 & $\begin{array}{c}-0.0678^{* * *} \\
(0.0141)\end{array}$ & $\begin{array}{c}-0.0676^{* * *} \\
(0.0139)\end{array}$ & $\begin{array}{c}-0.0681 * * * \\
(0.0139)\end{array}$ & $\begin{array}{c}-0.0672 * * * \\
(0.0139)\end{array}$ \\
\hline Region 3 & $\begin{array}{c}-0.0460 * * * \\
(0.0141)\end{array}$ & $\begin{array}{c}-0.0451 * * * \\
(0.0140)\end{array}$ & $\begin{array}{c}-0.0461 * * * \\
(0.0140)\end{array}$ & $\begin{array}{c}-0.0447 * * * \\
(0.0141)\end{array}$ \\
\hline Region 4 & $\begin{array}{c}-0.0410^{* * *} \\
(0.0138)\end{array}$ & $\begin{array}{c}-0.0406 * * * \\
(0.0136)\end{array}$ & $\begin{array}{c}-0.0413^{* * *} \\
(0.0136)\end{array}$ & $\begin{array}{c}-0.0403^{* * *} \\
(0.0136)\end{array}$ \\
\hline Region 5 & $\begin{array}{l}-0.0246 \\
(0.0186)\end{array}$ & $\begin{array}{l}-0.0249 \\
(0.0184)\end{array}$ & $\begin{array}{l}-0.0253 \\
(0.0184)\end{array}$ & $\begin{array}{l}-0.0239 \\
(0.0186)\end{array}$ \\
\hline Region 6 & $\begin{array}{c}-0.00615 \\
(0.0196)\end{array}$ & $\begin{array}{r}-0.00617 \\
(0.0194)\end{array}$ & $\begin{array}{r}-0.00644 \\
(0.0194)\end{array}$ & $\begin{array}{c}-0.00549 \\
(0.0195)\end{array}$ \\
\hline Region 7 & $\begin{array}{c}0.0102 \\
(0.0182)\end{array}$ & $\begin{array}{c}0.0115 \\
(0.0181)\end{array}$ & $\begin{array}{c}0.0110 \\
(0.0181)\end{array}$ & $\begin{array}{c}0.0123 \\
(0.0181)\end{array}$ \\
\hline Region 8 & $\begin{array}{c}-0.0388^{* * *} \\
(0.0144)\end{array}$ & $\begin{array}{c}-0.0378^{* * *} \\
(0.0143)\end{array}$ & $\begin{array}{c}-0.0384^{* * *} \\
(0.0144)\end{array}$ & $\begin{array}{c}-0.0374 * * * \\
(0.0144)\end{array}$ \\
\hline Region 9 & $\begin{array}{c}0.0424 \\
(0.0325)\end{array}$ & $\begin{array}{c}0.0475 \\
(0.0328)\end{array}$ & $\begin{array}{c}0.0441 \\
(0.0326)\end{array}$ & $\begin{array}{c}0.0473 \\
(0.0328)\end{array}$ \\
\hline Age at first marriage & $\begin{array}{c}0.00126 \\
(0.00115)\end{array}$ & $\begin{array}{c}0.00145 \\
(0.00115)\end{array}$ & $\begin{array}{c}0.00140 \\
(0.00115)\end{array}$ & $\begin{array}{c}0.00144 \\
(0.00114)\end{array}$ \\
\hline Husband works & $\begin{array}{l}0.00531 \\
(0.0232)\end{array}$ & $\begin{array}{l}0.00597 \\
(0.0228)\end{array}$ & $\begin{array}{l}0.00543 \\
(0.0231)\end{array}$ & $\begin{array}{l}0.00707 \\
(0.0226)\end{array}$ \\
\hline Husband Age & $\begin{array}{l}-0.000269 \\
(0.000926)\end{array}$ & $\begin{array}{l}-0.000231 \\
(0.000914)\end{array}$ & $\begin{array}{l}-0.000182 \\
(0.000921)\end{array}$ & $\begin{array}{l}-0.000248 \\
(0.000917)\end{array}$ \\
\hline Husband Education & $\begin{array}{c}2.98 \mathrm{e}-05 \\
(0.000353)\end{array}$ & $\begin{array}{c}5.14 \mathrm{e}-05 \\
(0.000353)\end{array}$ & $\begin{array}{c}5.03 \mathrm{e}-05 \\
(0.000353)\end{array}$ & $\begin{array}{c}2.49 \mathrm{e}-05 \\
(0.000355)\end{array}$ \\
\hline Indigenous & $\begin{array}{c}-0.00413 \\
(0.0120)\end{array}$ & $\begin{array}{c}-0.00204 \\
(0.0119)\end{array}$ & $\begin{array}{c}-0.00298 \\
(0.0119)\end{array}$ & $\begin{array}{c}-0.00252 \\
(0.0119)\end{array}$ \\
\hline Urban area & $\begin{array}{c}0.0296^{* *} \\
(0.0130)\end{array}$ & $\begin{array}{c}0.0281 * * \\
(0.0128)\end{array}$ & $\begin{array}{c}0.0283^{* *} \\
(0.0129)\end{array}$ & $\begin{array}{c}0.0287 * * \\
(0.0129)\end{array}$ \\
\hline Poverty Level & $\begin{array}{c}0.000125 \\
(0.000352)\end{array}$ & $\begin{array}{c}0.000142 \\
(0.000349)\end{array}$ & $\begin{array}{c}0.000132 \\
(0.000350)\end{array}$ & $\begin{array}{c}0.000136 \\
(0.000349)\end{array}$ \\
\hline Violence & & $\begin{array}{c}0.0249 * * * \\
(0.00844)\end{array}$ & & \\
\hline Physical Violence & & & $\begin{array}{c}0.0167 * * \\
(0.00792)\end{array}$ & \\
\hline Psychological Violence & & & & $\begin{array}{c}0.0215^{* * *} \\
(0.00810)\end{array}$ \\
\hline Observations & 7,095 & 7,095 & 7,095 & 7,095 \\
\hline
\end{tabular}


Table A2.2. Determinants of Job exit, by area and ethnicity

\begin{tabular}{|c|c|c|c|c|c|}
\hline VARIABLES & Full Sample & Urban & Rural & Indigenous & Non-Indigenous \\
\hline \multirow{2}{*}{ Age } & $-0.0194 * * *$ & $-0.0254 * * *$ & $-0.0102 *$ & $-0.0144 * *$ & $-0.0249 * * *$ \\
\hline & $(0.00435)$ & $(0.00608)$ & $(0.00526)$ & $(0.00561)$ & $(0.00581)$ \\
\hline \multirow[t]{2}{*}{ Age Squared } & $0.000196 * * *$ & $0.000262 * * *$ & 0.000103 & $0.000130^{*}$ & $0.000269^{* * *}$ \\
\hline & $(6.40 \mathrm{e}-05)$ & $(9.03 e-05)$ & $(7.34 \mathrm{e}-05)$ & $(7.76 \mathrm{e}-05)$ & $(8.70 \mathrm{e}-05)$ \\
\hline \multirow[t]{2}{*}{ Years of education } & 0.000626 & 0.00100 & 0.000626 & 0.00147 & 0.000273 \\
\hline & $(0.00154)$ & $(0.00225)$ & $(0.00175)$ & $(0.00210)$ & $(0.00226)$ \\
\hline \multirow[t]{2}{*}{ Currently Pregnant } & $0.0654 * * *$ & $0.0533^{*}$ & $0.0750 * * *$ & $0.0530^{*}$ & $0.0669 * *$ \\
\hline & $(0.0209)$ & $(0.0290)$ & $(0.0275)$ & $(0.0279)$ & $(0.0292)$ \\
\hline \multirow[t]{2}{*}{ Income $Q=2$} & 0.0106 & -0.0423 & 0.0190 & 0.0199 & -0.0180 \\
\hline & $(0.0161)$ & $(0.0388)$ & $(0.0126)$ & $(0.0169)$ & $(0.0225)$ \\
\hline \multirow[t]{2}{*}{ Income $Q=3$} & $0.0507 * *$ & 0.00695 & 0.0417 & $0.0800 * *$ & $4.86 \mathrm{e}-05$ \\
\hline & $(0.0234)$ & $(0.0538)$ & $(0.0302)$ & $(0.0312)$ & $(0.0287)$ \\
\hline \multirow[t]{2}{*}{ Income $\mathrm{Q}=4$} & 0.0191 & -0.0221 & -0.00791 & $0.0578^{*}$ & -0.0302 \\
\hline & $(0.0217)$ & $(0.0505)$ & $(0.0223)$ & $(0.0348)$ & $(0.0287)$ \\
\hline \multirow[t]{2}{*}{ Income $\mathrm{Q}=5$} & 0.0158 & -0.0251 & $-0.0510 * * *$ & 0.0623 & -0.0339 \\
\hline & $(0.0243)$ & $(0.0521)$ & $(0.00874)$ & $(0.0624)$ & $(0.0329)$ \\
\hline \multirow[t]{2}{*}{ No of Children 6 years or older } & $0.00509^{*}$ & 0.00247 & $0.00597 *$ & $0.00591 *$ & 0.00479 \\
\hline & $(0.00294)$ & $(0.00432)$ & $(0.00343)$ & $(0.00333)$ & $(0.00491)$ \\
\hline \multirow[t]{2}{*}{ No of Children 5 years or younger } & 0.00203 & -0.00403 & 0.00685 & 0.00701 & -0.00568 \\
\hline & $(0.00570)$ & $(0.00878)$ & $(0.00521)$ & $(0.00542)$ & $(0.0102)$ \\
\hline \multirow[t]{2}{*}{ Region 2} & $-0.0676^{* * *}$ & -0.0286 & $-0.0849 * * *$ & $-0.0686 * * *$ & $-0.0577^{* *}$ \\
\hline & $(0.0139)$ & $(0.0261)$ & $(0.0112)$ & $(0.0151)$ & $(0.0235)$ \\
\hline \multirow[t]{2}{*}{ Region 3} & $-0.0451^{* * *}$ & -0.0130 & $-0.0577 * * *$ & $-0.0476 * * *$ & -0.0274 \\
\hline & $(0.0140)$ & $(0.0260)$ & $(0.0120)$ & $(0.0144)$ & $(0.0255)$ \\
\hline \multirow[t]{2}{*}{ Region 4} & $-0.0406^{* * *}$ & 0.00976 & $-0.0549 * * *$ & $-0.0513^{* * *}$ & -0.00897 \\
\hline & $(0.0136)$ & $(0.0313)$ & $(0.00724)$ & $(0.00932)$ & $(0.0283)$ \\
\hline \multirow[t]{2}{*}{ Region 5} & -0.0249 & 0.0199 & $-0.0416^{* * *}$ & -0.0217 & -0.0398 \\
\hline & $(0.0184)$ & $(0.0365)$ & $(0.0125)$ & $(0.0172)$ & $(0.0247)$ \\
\hline \multirow[t]{2}{*}{ Region 6} & -0.00617 & 0.0370 & -0.0182 & 0.00929 & 0.000457 \\
\hline & $(0.0194)$ & $(0.0342)$ & $(0.0219)$ & $(0.0363)$ & $(0.0276)$ \\
\hline \multirow[t]{2}{*}{ Region 7} & 0.0115 & $0.0519 *$ & 0.0100 & 0.00130 & 0.0302 \\
\hline & $(0.0181)$ & $(0.0297)$ & $(0.0195)$ & $(0.0223)$ & $(0.0258)$ \\
\hline \multirow[t]{2}{*}{ Region 8} & $-0.0378^{* * *}$ & -0.00245 & $-0.0405^{* * *}$ & $-0.0580 * * *$ & -0.0322 \\
\hline & $(0.0143)$ & $(0.0293)$ & $(0.0117)$ & $(0.00795)$ & $(0.0231)$ \\
\hline \multirow[t]{2}{*}{ Region 9} & 0.0475 & $0.115^{* *}$ & 0.00996 & -0.00851 & $0.0780 *$ \\
\hline & $(0.0328)$ & $(0.0557)$ & $(0.0364)$ & $(0.0608)$ & $(0.0452)$ \\
\hline \multirow[t]{2}{*}{ Age at first marriage } & 0.00145 & 0.00215 & 0.000277 & 0.00120 & 0.00235 \\
\hline & $(0.00115)$ & $(0.00154)$ & $(0.00150)$ & $(0.00147)$ & $(0.00186)$ \\
\hline Husband works & 0.00597 & 0.00766 & 0.00319 & $0.0443^{* * *}$ & -0.0171 \\
\hline & $(0.0228)$ & $(0.0287)$ & $(0.0347)$ & $(0.0132)$ & $(0.0355)$ \\
\hline Husband Age & -0.000231 & 0.000352 & -0.00116 & $4.16 \mathrm{e}-05$ & -0.000357 \\
\hline & $(0.000914)$ & $(0.00138)$ & $(0.000827)$ & $(0.000966)$ & $(0.00130)$ \\
\hline Husband Education & $5.14 \mathrm{e}-05$ & -0.000398 & 0.000355 & 0.000130 & $8.39 \mathrm{e}-05$ \\
\hline & $(0.000353)$ & $(0.000544)$ & $(0.000335)$ & $(0.000328)$ & $(0.000677)$ \\
\hline Indigenous & -0.00204 & 0.00742 & 0.00830 & & \\
\hline & $(0.0119)$ & $(0.0173)$ & $(0.0138)$ & & \\
\hline Urban area & $0.0281 * *$ & & & 0.0227 & $0.0311^{*}$ \\
\hline & $(0.0128)$ & & & $(0.0165)$ & $(0.0169)$ \\
\hline Poverty Level & 0.000142 & $6.21 \mathrm{e}-05$ & -0.000157 & 0.000593 & -0.000121 \\
\hline & $(0.000349)$ & $(0.000439)$ & $(0.000524)$ & $(0.000420)$ & $(0.000493)$ \\
\hline Violence & $0.0249 * * *$ & $0.0269 * *$ & $0.0173^{*}$ & 0.00969 & $0.0390 * * *$ \\
\hline & $(0.00844)$ & $(0.0118)$ & $(0.00995)$ & $(0.0102)$ & $(0.0121)$ \\
\hline Observations & 7,095 & 4,456 & 2,639 & 2,946 & 4,149 \\
\hline
\end{tabular}

Robust standard errors in parentheses ${ }^{* * *} \mathrm{p}<0.01,{ }^{* *} \mathrm{p}<0.05,{ }^{*} \mathrm{p}<0.1$ 
Table A2.3. Determinants of Job Exit, Entire Sample by income group

\begin{tabular}{|c|c|c|c|c|c|}
\hline VARIABLES & Q1 & Q2 & Q3 & Q4 & Q5 \\
\hline Age & $\begin{array}{l}-0.00966 \\
(0.00696)\end{array}$ & $\begin{array}{l}-0.0104 * \\
(0.00627)\end{array}$ & $\begin{array}{c}-0.0406 * * * \\
(0.0110)\end{array}$ & $\begin{array}{c}-0.0197 * * \\
(0.00936)\end{array}$ & $\begin{array}{c}-0.0180^{*} \\
(0.0108)\end{array}$ \\
\hline Age Squared & $\begin{array}{c}9.12 \mathrm{e}-05 \\
(9.77 \mathrm{e}-05)\end{array}$ & $\begin{array}{c}0.000109 \\
(8.78 \mathrm{e}-05)\end{array}$ & $\begin{array}{c}0.000446 * * \\
(0.000177)\end{array}$ & $\begin{array}{c}0.000205 \\
(0.000139)\end{array}$ & $\begin{array}{c}0.000162 \\
(0.000146)\end{array}$ \\
\hline Years of education & $\begin{array}{c}0.00365 \\
(0.00347)\end{array}$ & $\begin{array}{c}0.00127 \\
(0.00181)\end{array}$ & $\begin{array}{c}-0.000613 \\
(0.00335)\end{array}$ & $\begin{array}{c}0.00181 \\
(0.00324)\end{array}$ & $\begin{array}{c}-0.000142 \\
(0.00357)\end{array}$ \\
\hline Currently Pregnant & $\begin{array}{c}0.0450 \\
(0.0313)\end{array}$ & $\begin{array}{c}0.129 * * * \\
(0.0455)\end{array}$ & $\begin{array}{c}0.0802 \\
(0.0513)\end{array}$ & $\begin{array}{l}0.00418 \\
(0.0369)\end{array}$ & $\begin{array}{c}0.0661 \\
(0.0527)\end{array}$ \\
\hline No of Children 6 years or older & $\begin{array}{l}0.0107 * * \\
(0.00445)\end{array}$ & $\begin{array}{c}-0.000467 \\
(0.00397)\end{array}$ & $\begin{array}{c}0.0106 \\
(0.00879)\end{array}$ & $\begin{array}{l}-0.00715 \\
(0.00679)\end{array}$ & $\begin{array}{c}0.00789 \\
(0.00800)\end{array}$ \\
\hline No of Children 5 years or younger & $\begin{array}{c}0.00717 \\
(0.00703)\end{array}$ & $\begin{array}{l}0.0154^{* *} \\
(0.00721)\end{array}$ & $\begin{array}{l}-0.0175 \\
(0.0133)\end{array}$ & $\begin{array}{l}-0.00557 \\
(0.0162)\end{array}$ & $\begin{array}{c}-0.00398 \\
(0.0151)\end{array}$ \\
\hline Region 2 & $\begin{array}{c}-0.0862 * * * \\
(0.0161)\end{array}$ & $\begin{array}{c}-0.0942^{* * * *} \\
(0.0214)\end{array}$ & $\begin{array}{l}-0.0616 \\
(0.0427)\end{array}$ & $\begin{array}{l}-0.0283 \\
(0.0364)\end{array}$ & $\begin{array}{l}-0.00911 \\
(0.0293)\end{array}$ \\
\hline Region 3 & $\begin{array}{c}-0.0539 * * * \\
(0.0170)\end{array}$ & $\begin{array}{c}-0.0435^{* * * *} \\
(0.0168)\end{array}$ & $\begin{array}{c}-0.0701^{* *} \\
(0.0340)\end{array}$ & $\begin{array}{r}-0.00356 \\
(0.0401)\end{array}$ & $\begin{array}{c}-0.00889 \\
(0.0331)\end{array}$ \\
\hline Region 4 & & $\begin{array}{c}-0.0355^{* *} \\
(0.0143)\end{array}$ & $\begin{array}{l}-0.0419 \\
(0.0367)\end{array}$ & $\begin{array}{l}0.00637 \\
(0.0500)\end{array}$ & $\begin{array}{l}0.00425 \\
(0.0496)\end{array}$ \\
\hline Region 5 & $\begin{array}{c}-0.0492 * * * \\
(0.0170)\end{array}$ & $\begin{array}{l}-0.0297 \\
(0.0191)\end{array}$ & $\begin{array}{c}0.0436 \\
(0.0609)\end{array}$ & $\begin{array}{l}-0.0105 \\
(0.0437)\end{array}$ & $\begin{array}{l}-0.0373 \\
(0.0301)\end{array}$ \\
\hline Region 6 & $\begin{array}{c}-0.0492 * * * \\
(0.0109)\end{array}$ & $\begin{array}{c}0.0243 \\
(0.0458)\end{array}$ & $\begin{array}{l}0.00813 \\
(0.0567)\end{array}$ & $\begin{array}{c}0.0660 \\
(0.0571)\end{array}$ & $\begin{array}{l}0.00549 \\
(0.0336)\end{array}$ \\
\hline Region 7 & $\begin{array}{l}-0.00963 \\
(0.0225)\end{array}$ & $\begin{array}{c}0.0385 \\
(0.0358)\end{array}$ & $\begin{array}{l}-0.0394 \\
(0.0404)\end{array}$ & $\begin{array}{c}0.0568 \\
(0.0451)\end{array}$ & $\begin{array}{c}0.0787 * * \\
(0.0383)\end{array}$ \\
\hline Region 8 & $\begin{array}{c}-0.0413^{* * *} \\
(0.0143)\end{array}$ & $\begin{array}{c}0.0174 \\
(0.0397)\end{array}$ & $\begin{array}{c}-0.0862 * * * \\
(0.0283)\end{array}$ & $\begin{array}{l}-0.0261 \\
(0.0376)\end{array}$ & $\begin{array}{l}-0.0365 \\
(0.0273)\end{array}$ \\
\hline Region 9 & $\begin{array}{l}-0.00585 \\
(0.0400)\end{array}$ & $\begin{array}{c}0.0923 \\
(0.0750)\end{array}$ & $\begin{array}{l}-0.0240 \\
(0.0526)\end{array}$ & $\begin{array}{c}0.0612 \\
(0.0813)\end{array}$ & $\begin{array}{c}0.156 \\
(0.112)\end{array}$ \\
\hline Age at first marriage & $\begin{array}{l}0.000324 \\
(0.00218)\end{array}$ & $\begin{array}{c}0.00218 \\
(0.00168)\end{array}$ & $\begin{array}{l}0.00648^{*} \\
(0.00377)\end{array}$ & $\begin{array}{c}0.00379 \\
(0.00280)\end{array}$ & $\begin{array}{c}-0.00383^{*} \\
(0.00212)\end{array}$ \\
\hline Husband works & & $\begin{array}{c}0.0201 \\
(0.0274)\end{array}$ & $\begin{array}{c}0.0330 \\
(0.0496)\end{array}$ & $\begin{array}{c}0.0509 \\
(0.0345)\end{array}$ & $\begin{array}{l}-0.0492 \\
(0.0532)\end{array}$ \\
\hline Husband Age & $\begin{array}{c}-0.00220^{* *} \\
(0.00112)\end{array}$ & $\begin{array}{l}0.000187 \\
(0.00114)\end{array}$ & $\begin{array}{c}-0.000223 \\
(0.00308)\end{array}$ & $\begin{array}{l}0.000438 \\
(0.00183)\end{array}$ & $\begin{array}{l}0.000172 \\
(0.00161)\end{array}$ \\
\hline Husband Education & $\begin{array}{c}0.000243 \\
(0.000425)\end{array}$ & $\begin{array}{c}0.000497 \\
(0.000509)\end{array}$ & $\begin{array}{l}-0.000487 \\
(0.000895)\end{array}$ & $\begin{array}{l}-4.74 \mathrm{e}-05 \\
(0.000857)\end{array}$ & $\begin{array}{l}0.000706 \\
(0.00109)\end{array}$ \\
\hline Indigenous & $\begin{array}{l}-0.0111 \\
(0.0222)\end{array}$ & $\begin{array}{c}0.0166 \\
(0.0167)\end{array}$ & $\begin{array}{l}-0.0162 \\
(0.0222)\end{array}$ & $\begin{array}{c}0.0210 \\
(0.0352)\end{array}$ & $\begin{array}{l}0.00850 \\
(0.0374)\end{array}$ \\
\hline Urban area & $\begin{array}{c}0.0169 \\
(0.0361)\end{array}$ & $\begin{array}{l}-0.0120 \\
(0.0139)\end{array}$ & $\begin{array}{c}0.0439 \\
(0.0270)\end{array}$ & $\begin{array}{c}0.0523 * * \\
(0.0250)\end{array}$ & $\begin{array}{c}0.0814^{* * *} \\
(0.00960)\end{array}$ \\
\hline Poverty Level & $\begin{array}{c}0.000322 \\
(0.000905)\end{array}$ & $\begin{array}{l}-0.000521 \\
(0.000547)\end{array}$ & $\begin{array}{l}-0.000343 \\
(0.000693)\end{array}$ & $\begin{array}{c}0.000101 \\
(0.000687)\end{array}$ & $\begin{array}{c}0.000622 \\
(0.000682)\end{array}$ \\
\hline Violence & $\begin{array}{c}0.0144 \\
(0.0141)\end{array}$ & $\begin{array}{c}0.0399 * * * \\
(0.0122)\end{array}$ & $\begin{array}{c}0.0110 \\
(0.0277)\end{array}$ & $\begin{array}{c}0.0258 \\
(0.0202)\end{array}$ & $\begin{array}{c}0.0110 \\
(0.0170)\end{array}$ \\
\hline Observations & 1,072 & 1,419 & 1,521 & 1,592 & 1,397 \\
\hline
\end{tabular}


Table A2.4. Determinants of Job Exit, Indigenous people by income group

\begin{tabular}{|c|c|c|c|c|}
\hline VARIABLES & Q1 & Q2 & Q3 & Q4-Q5 \\
\hline Age & $\begin{array}{c}-0.0116 \\
(0.00743)\end{array}$ & $\begin{array}{c}-0.00991 \\
(0.00741)\end{array}$ & $\begin{array}{c}-0.0317^{* *} \\
(0.0151)\end{array}$ & $\begin{array}{l}-0.0118 \\
(0.0128)\end{array}$ \\
\hline Age Squared & $\begin{array}{c}0.000115 \\
(0.000104)\end{array}$ & $\begin{array}{c}5.68 \mathrm{e}-05 \\
(0.000104)\end{array}$ & $\begin{array}{c}0.000310 \\
(0.000204)\end{array}$ & $\begin{array}{c}0.000129 \\
(0.000178)\end{array}$ \\
\hline Years of education & $\begin{array}{c}0.00652 \\
(0.00409)\end{array}$ & $\begin{array}{l}1.34 \mathrm{e}-05 \\
(0.00199)\end{array}$ & $\begin{array}{c}9.95 \mathrm{e}-05 \\
(0.00476)\end{array}$ & $\begin{array}{c}0.00154 \\
(0.00432)\end{array}$ \\
\hline Currently Pregnant & $\begin{array}{c}0.0305 \\
(0.0287)\end{array}$ & $\begin{array}{l}0.0687^{*} \\
(0.0416)\end{array}$ & $\begin{array}{c}0.113 \\
(0.114)\end{array}$ & $\begin{array}{c}-0.00970 \\
(0.0495)\end{array}$ \\
\hline No of Children 6 years or older & $\begin{array}{l}0.00828^{*} \\
(0.00475)\end{array}$ & $\begin{array}{l}0.00620^{*} \\
(0.00370)\end{array}$ & $\begin{array}{c}0.0142 \\
(0.0119)\end{array}$ & $\begin{array}{c}-0.0111 \\
(0.00695)\end{array}$ \\
\hline No of Children 5 years or younger & $\begin{array}{c}0.0109 \\
(0.00754)\end{array}$ & $\begin{array}{c}0.0132 * \\
(0.00704)\end{array}$ & $\begin{array}{c}-0.000474 \\
(0.0162)\end{array}$ & $\begin{array}{l}-0.0222 \\
(0.0163)\end{array}$ \\
\hline Region 2 & $\begin{array}{c}-0.0909 * * * \\
(0.0185)\end{array}$ & $\begin{array}{c}-0.0389 * \\
(0.0217)\end{array}$ & $\begin{array}{l}-0.0830 \\
(0.0531)\end{array}$ & $\begin{array}{l}-0.0123 \\
(0.0428)\end{array}$ \\
\hline Region 3 & $\begin{array}{c}-0.0631^{* * *} \\
(0.0174)\end{array}$ & $\begin{array}{c}-0.00613 \\
(0.0213)\end{array}$ & $\begin{array}{c}-0.0920^{* *} \\
(0.0388)\end{array}$ & $\begin{array}{l}-0.0509 \\
(0.0346)\end{array}$ \\
\hline Region 4 & & $\begin{array}{l}0.00318 \\
(0.0284)\end{array}$ & $\begin{array}{c}-0.0835^{* * *} \\
(0.0280)\end{array}$ & $\begin{array}{l}-0.0192 \\
(0.0500)\end{array}$ \\
\hline Region 5 & $\begin{array}{c}-0.0518^{* * *} \\
(0.0141)\end{array}$ & $\begin{array}{c}0.0121 \\
(0.0305)\end{array}$ & $\begin{array}{c}0.0514 \\
(0.0770)\end{array}$ & $\begin{array}{l}-0.0385 \\
(0.0305)\end{array}$ \\
\hline Region 6 & & $\begin{array}{c}0.242 \\
(0.168)\end{array}$ & $\begin{array}{l}0.0819 \\
(0.117)\end{array}$ & $\begin{array}{l}-0.0233 \\
(0.0346)\end{array}$ \\
\hline Region 7 & $\begin{array}{l}-0.0107 \\
(0.0228)\end{array}$ & $\begin{array}{c}0.123 \\
(0.0842)\end{array}$ & $\begin{array}{l}-0.0560 \\
(0.0423)\end{array}$ & $\begin{array}{c}0.0120 \\
(0.0477)\end{array}$ \\
\hline Region 8 & & & & $\begin{array}{c}-0.0460 \\
(0.0310)\end{array}$ \\
\hline Region 9 & & & $\begin{array}{c}0.158 \\
(0.280)\end{array}$ & \\
\hline Age at first marriage & $\begin{array}{c}0.00165 \\
(0.00228)\end{array}$ & $\begin{array}{c}0.00207 \\
(0.00164)\end{array}$ & $\begin{array}{l}0.00927 * \\
(0.00483)\end{array}$ & $\begin{array}{l}-0.00474 \\
(0.00308)\end{array}$ \\
\hline Husband works & & $\begin{array}{c}0.0204 \\
(0.0188)\end{array}$ & $\begin{array}{c}0.0473 \\
(0.0495)\end{array}$ & \\
\hline Husband Age & $\begin{array}{l}-0.000160 \\
(0.000962)\end{array}$ & $\begin{array}{c}0.00169 \\
(0.00125)\end{array}$ & $\begin{array}{c}1.30 \mathrm{e}-05 \\
(0.00277)\end{array}$ & $\begin{array}{l}-0.00180 \\
(0.00214)\end{array}$ \\
\hline Husband Education & $\begin{array}{c}0.000300 \\
(0.000367)\end{array}$ & $\begin{array}{c}0.000493 \\
(0.000386)\end{array}$ & $\begin{array}{c}-0.000272 \\
(0.00105)\end{array}$ & $\begin{array}{c}-0.00151^{* *} \\
(0.000630)\end{array}$ \\
\hline Urban area & & $\begin{array}{c}0.000563 \\
(0.0161)\end{array}$ & $\begin{array}{c}0.0279 \\
(0.0333)\end{array}$ & $\begin{array}{c}0.0609 * * * \\
(0.0195)\end{array}$ \\
\hline Poverty Level & $\begin{array}{c}0.00135 \\
(0.00107)\end{array}$ & $\begin{array}{c}0.000289 \\
(0.000576)\end{array}$ & $\begin{array}{c}0.000509 \\
(0.000801)\end{array}$ & $\begin{array}{l}-0.000969 \\
(0.000775)\end{array}$ \\
\hline Violence & $\begin{array}{r}-0.00329 \\
(0.0148)\end{array}$ & $\begin{array}{c}0.0163 \\
(0.0123)\end{array}$ & $\begin{array}{l}-0.0395 \\
(0.0345)\end{array}$ & $\begin{array}{c}0.0531 * * \\
(0.0216)\end{array}$ \\
\hline Income $Q=4$ & & & & $\begin{array}{c}0.0110 \\
(0.0313)\end{array}$ \\
\hline Observations & 717 & 816 & 648 & 628 \\
\hline
\end{tabular}

Robust standard errors in parentheses

*** $\mathrm{p}<0.01,{ }^{* *} \mathrm{p}<0.05,{ }^{*} \mathrm{p}<0.1$ 
Table A2.5 Determinants of Job Exit, Non-indigenous people by income group

\begin{tabular}{|c|c|c|c|c|}
\hline VARIABLES & Q1-Q2 & Q3 & Q4 & Q5 \\
\hline Age & $\begin{array}{l}-0.0164 * \\
(0.00904)\end{array}$ & $\begin{array}{c}-0.0457 * * * \\
(0.0150)\end{array}$ & $\begin{array}{c}-0.0295^{* * *} \\
(0.0111)\end{array}$ & $\begin{array}{c}-0.0192 * \\
(0.0107)\end{array}$ \\
\hline Age Squared & $\begin{array}{c}0.000265^{* *} \\
(0.000128)\end{array}$ & $\begin{array}{c}0.000522^{* *} \\
(0.000255)\end{array}$ & $\begin{array}{l}0.000312^{*} \\
(0.000164)\end{array}$ & $\begin{array}{r}0.000164 \\
(0.000145)\end{array}$ \\
\hline Years of education & $\begin{array}{c}0.00311 \\
(0.00311)\end{array}$ & $\begin{array}{l}-0.00154 \\
(0.00392)\end{array}$ & $\begin{array}{c}-0.000570 \\
(0.00322)\end{array}$ & $\begin{array}{l}0.000621 \\
(0.00412)\end{array}$ \\
\hline Currently Pregnant & $\begin{array}{c}0.182^{* * *} \\
(0.0559)\end{array}$ & $\begin{array}{c}0.0478 \\
(0.0607)\end{array}$ & $\begin{array}{l}-0.0124 \\
(0.0383)\end{array}$ & $\begin{array}{c}0.0896 \\
(0.0590)\end{array}$ \\
\hline No of Children 6 years or older & $\begin{array}{l}-0.00485 \\
(0.00731)\end{array}$ & $\begin{array}{c}0.0104 \\
(0.0114)\end{array}$ & $\begin{array}{c}0.00228 \\
(0.00923)\end{array}$ & $\begin{array}{c}0.0117 \\
(0.00909)\end{array}$ \\
\hline No of Children 5 years or younger & $\begin{array}{l}0.00682 \\
(0.0115)\end{array}$ & $\begin{array}{c}-0.0420^{*} \\
(0.0230)\end{array}$ & $\begin{array}{c}-0.00629 \\
(0.0213)\end{array}$ & $\begin{array}{l}0.00381 \\
(0.0163)\end{array}$ \\
\hline Region 2 & $\begin{array}{c}-0.144 * * * \\
(0.0223)\end{array}$ & $\begin{array}{l}-0.0314 \\
(0.0788)\end{array}$ & $\begin{array}{c}-0.000854 \\
(0.0546)\end{array}$ & $\begin{array}{l}-0.0132 \\
(0.0354)\end{array}$ \\
\hline Region 3 & $\begin{array}{c}-0.0771 * * * \\
(0.0252)\end{array}$ & $\begin{array}{c}-0.00130 \\
(0.0814)\end{array}$ & $\begin{array}{c}0.0685 \\
(0.0732)\end{array}$ & $\begin{array}{l}0.00277 \\
(0.0411)\end{array}$ \\
\hline Region 4 & $\begin{array}{c}-0.0875^{* * *} * \\
(0.0164)\end{array}$ & $\begin{array}{c}0.0547 \\
(0.0917)\end{array}$ & $\begin{array}{c}0.0782 \\
(0.0838)\end{array}$ & $\begin{array}{l}-0.0118 \\
(0.0483)\end{array}$ \\
\hline Region 5 & $\begin{array}{c}-0.0945^{* * *} \\
(0.0156)\end{array}$ & $\begin{array}{c}0.0140 \\
(0.0820)\end{array}$ & $\begin{array}{c}0.0102 \\
(0.0590)\end{array}$ & $\begin{array}{l}-0.0286 \\
(0.0366)\end{array}$ \\
\hline Region 6 & $\begin{array}{c}-0.0780^{* * *} \\
(0.0270)\end{array}$ & $\begin{array}{c}0.0249 \\
(0.0881)\end{array}$ & $\begin{array}{c}0.137 \\
(0.0843)\end{array}$ & $\begin{array}{l}0.00524 \\
(0.0375)\end{array}$ \\
\hline Region 7 & $\begin{array}{l}-0.0253 \\
(0.0392)\end{array}$ & $\begin{array}{c}0.000328 \\
(0.0704)\end{array}$ & $\begin{array}{c}0.106^{*} \\
(0.0601)\end{array}$ & $\begin{array}{c}0.0869 * * \\
(0.0434)\end{array}$ \\
\hline Region 8 & $\begin{array}{c}-0.0634^{* *} \\
(0.0297)\end{array}$ & $\begin{array}{l}-0.0626 \\
(0.0543)\end{array}$ & $\begin{array}{l}0.00611 \\
(0.0585)\end{array}$ & $\begin{array}{c}-0.0328 \\
(0.0318)\end{array}$ \\
\hline Region 9 & $\begin{array}{c}0.0187 \\
(0.0628)\end{array}$ & $\begin{array}{c}0.0186 \\
(0.0899)\end{array}$ & $\begin{array}{c}0.123 \\
(0.113)\end{array}$ & $\begin{array}{c}0.156 \\
(0.117)\end{array}$ \\
\hline Age at first marriage & $\begin{array}{l}0.000978 \\
(0.00322)\end{array}$ & $\begin{array}{c}0.00377 \\
(0.00509)\end{array}$ & $\begin{array}{c}0.00938^{* *} \\
(0.00377)\end{array}$ & $\begin{array}{r}-0.00322 \\
(0.00223)\end{array}$ \\
\hline Husband works & $\begin{array}{c}0.0179 \\
(0.0769)\end{array}$ & $\begin{array}{c}0.0304 \\
(0.0685)\end{array}$ & $\begin{array}{c}0.0335 \\
(0.0476)\end{array}$ & $\begin{array}{l}-0.0693 \\
(0.0610)\end{array}$ \\
\hline Husband Age & $\begin{array}{c}-0.00362^{* *} \\
(0.00169)\end{array}$ & $\begin{array}{c}-0.000987 \\
(0.00403)\end{array}$ & $\begin{array}{l}0.000991 \\
(0.00230)\end{array}$ & $\begin{array}{c}0.00121 \\
(0.00157)\end{array}$ \\
\hline Husband Education & $\begin{array}{l}-0.000760 \\
(0.000789)\end{array}$ & $\begin{array}{c}-0.000459 \\
(0.00147)\end{array}$ & $\begin{array}{c}0.00138 \\
(0.00127)\end{array}$ & $\begin{array}{c}-2.84 \mathrm{e}-05 \\
(0.00154)\end{array}$ \\
\hline Urban area & $\begin{array}{c}-0.00789 \\
(0.0243)\end{array}$ & $\begin{array}{c}0.0416 \\
(0.0358)\end{array}$ & $\begin{array}{c}0.0418 \\
(0.0331)\end{array}$ & $\begin{array}{c}0.0816 * * * \\
(0.0117)\end{array}$ \\
\hline Poverty Level & $\begin{array}{c}-0.00200^{*} \\
(0.00102)\end{array}$ & $\begin{array}{c}-0.000852 \\
(0.00114)\end{array}$ & $\begin{array}{c}0.000953 \\
(0.000903)\end{array}$ & $\begin{array}{c}0.000776 \\
(0.000816)\end{array}$ \\
\hline Violence & $\begin{array}{c}0.0932^{* * *} \\
(0.0185)\end{array}$ & $\begin{array}{l}0.0646 * \\
(0.0342)\end{array}$ & $\begin{array}{c}0.0168 \\
(0.0247)\end{array}$ & $\begin{array}{l}0.00138 \\
(0.0189)\end{array}$ \\
\hline Income $\mathrm{Q}=2$ & $\begin{array}{l}0.00412 \\
(0.0214)\end{array}$ & & & \\
\hline Observations & 934 & 869 & 1,125 & 1,221 \\
\hline
\end{tabular}

Robust standard errors in parentheses

*** $\mathrm{p}<0.01,{ }^{* *} \mathrm{p}<0.05,{ }^{*} \mathrm{p}<0.1$ 
Table A2.6. Determinants of Job exit, Entire Sample and Different corrections

\begin{tabular}{|c|c|c|c|c|}
\hline \multirow[b]{2}{*}{ VARIABLES } & \multirow[b]{2}{*}{ Probit } & \multirow[b]{2}{*}{ IV Probit } & \multicolumn{2}{|c|}{ Treat-Selection } \\
\hline & & & LPM & Selec EQ \\
\hline \multirow[t]{2}{*}{ Age } & $-0.0194 * * *$ & $-0.0198^{* * *}$ & $-0.0313^{* * *}$ & \\
\hline & $(0.00435)$ & $(0.00440)$ & $(0.00566)$ & \\
\hline \multirow[t]{2}{*}{ Age Squared } & $0.000196^{* * * *}$ & $0.000202^{* * *}$ & $0.000364 * * *$ & \\
\hline & $(6.40 \mathrm{e}-05)$ & $(6.41 \mathrm{e}-05)$ & $(7.73 \mathrm{e}-05)$ & \\
\hline \multirow[t]{2}{*}{ Years of education } & 0.000626 & 0.000764 & 0.000914 & $-0.00668^{*}$ \\
\hline & $(0.00154)$ & $(0.00155)$ & $(0.00159)$ & $(0.00364)$ \\
\hline \multirow[t]{2}{*}{ Currently Pregnant } & $0.0654 * * *$ & $0.0687 * * *$ & $0.0753 * * *$ & $-0.194 * * *$ \\
\hline & $(0.0209)$ & $(0.0219)$ & $(0.0234)$ & $(0.0693)$ \\
\hline \multirow[t]{2}{*}{ Income $Q=2$} & 0.0106 & 0.00814 & 0.00734 & \\
\hline & $(0.0161)$ & $(0.0162)$ & $(0.0132)$ & \\
\hline \multirow[t]{2}{*}{ Income $Q=3$} & $0.0507 * *$ & $0.0485^{* *}$ & $0.0423^{* *}$ & \\
\hline & $(0.0234)$ & $(0.0232)$ & $(0.0192)$ & \\
\hline \multirow{2}{*}{ Income $Q=4$} & 0.0191 & 0.0174 & 0.00922 & \\
\hline & $(0.0217)$ & $(0.0219)$ & $(0.0204)$ & \\
\hline \multirow{2}{*}{ Income $Q=5$} & 0.0158 & 0.0166 & 0.00693 & \\
\hline & $(0.0243)$ & $(0.0244)$ & $(0.0237)$ & \\
\hline \multirow[t]{2}{*}{ No of Children 6 years or older } & $0.00509^{*}$ & 0.00453 & $0.00497 * *$ & \\
\hline & $(0.00294)$ & $(0.00295)$ & $(0.00246)$ & \\
\hline \multirow[t]{2}{*}{ No of Children 5 years or younger } & 0.00203 & 0.00239 & -0.000655 & \\
\hline & $(0.00570)$ & $(0.00567)$ & $(0.00615)$ & \\
\hline Region 2 & $-0.0676^{* * *}$ & $-0.0676^{* * *}$ & $-0.0729 * * *$ & \\
\hline & $(0.0139)$ & $(0.0139)$ & $(0.0210)$ & \\
\hline Region 3 & $-0.0451^{* * *}$ & $-0.0445^{* * *}$ & $-0.0512^{* *}$ & \\
\hline & $(0.0140)$ & $(0.0140)$ & $(0.0206)$ & \\
\hline Region 4 & $-0.0406^{* * *}$ & $-0.0404 * * *$ & $-0.0507 * *$ & \\
\hline & $(0.0136)$ & $(0.0136)$ & $(0.0224)$ & \\
\hline Region 5 & -0.0249 & -0.0249 & -0.0298 & \\
\hline & $(0.0184)$ & $(0.0185)$ & $(0.0254)$ & \\
\hline Region 6 & -0.00617 & -0.00626 & -0.00319 & \\
\hline & $(0.0194)$ & $(0.0192)$ & $(0.0257)$ & \\
\hline Region 7 & 0.0115 & 0.0133 & 0.0244 & \\
\hline & $(0.0181)$ & $(0.0180)$ & $(0.0218)$ & \\
\hline Region 8 & $-0.0378^{* * *}$ & $-0.0367 * *$ & $-0.0422^{*}$ & \\
\hline & $(0.0143)$ & $(0.0144)$ & $(0.0236)$ & \\
\hline Region 9 & 0.0475 & 0.0537 & $0.0826^{* *}$ & \\
\hline & $(0.0328)$ & $(0.0330)$ & $(0.0362)$ & \\
\hline Age at first marriage & 0.00145 & 0.00156 & 0.00165 & $-0.0865^{* * *}$ \\
\hline & $(0.00115)$ & $(0.00116)$ & $(0.00102)$ & $(0.0270)$ \\
\hline Husband works & 0.00597 & 0.00872 & 0.00481 & \\
\hline & $(0.0228)$ & $(0.0224)$ & $(0.0274)$ & \\
\hline Husband Age & -0.000231 & -0.000206 & -0.000412 & \\
\hline & $(0.000914)$ & $(0.000917)$ & $(0.000929)$ & \\
\hline Husband Education & $5.14 \mathrm{e}-05$ & $7.18 \mathrm{e}-05$ & $3.31 \mathrm{e}-05$ & \\
\hline & $(0.000353)$ & $(0.000356)$ & $(0.000346)$ & \\
\hline Indigenous & -0.00204 & -0.000459 & 0.00284 & \\
\hline & $(0.0119)$ & $(0.0119)$ & $(0.0127)$ & \\
\hline Urban area & $0.0281 * *$ & $0.0267 * *$ & $0.0270^{* *}$ & \\
\hline & $(0.0128)$ & $(0.0130)$ & $(0.0137)$ & \\
\hline Poverty Level & 0.000142 & 0.000147 & $3.92 \mathrm{e}-06$ & \\
\hline & $(0.000349)$ & $(0.000349)$ & $(0.000371)$ & \\
\hline Violence & $0.0249 * * *$ & $0.0530 * *$ & $0.0638^{* * *}$ & \\
\hline & $(0.00844)$ & $(0.0237)$ & $(0.0215)$ & \\
\hline Reg. Violence & & & & $2.918^{* * *}$ \\
\hline & & & & $(0.0915)$ \\
\hline Intergenerational Violence & & & & $0.271 * * *$ \\
\hline & & & & $(0.0396)$ \\
\hline Accepts Violence & & & & $0.202^{* * *}$ \\
\hline & & & & $(0.0527)$ \\
\hline Age at first Marriage`2 & & & & $0.00172^{* * *}$ \\
\hline & & & & $(0.000598)$ \\
\hline Cosntant & & & $0.637 * * *$ & $-0.547^{*}$ \\
\hline & & & $(0.108)$ & $(0.302)$ \\
\hline Exogeneity Test (chi2 k=1) & & $1.55(\mathrm{p}=0.2131)$ & & \\
\hline Observations & 7,095 & 7,095 & 7,092 & 7,092 \\
\hline
\end{tabular}

Robust standard errors in parentheses

*** $\mathrm{p}<0.01,{ }^{* *} \mathrm{p}<0.05,{ }^{*} \mathrm{p}<0.1$ 
Table A2.7. Determinants of Job exit, Entire Sample and Different corrections. By area

\begin{tabular}{|c|c|c|c|c|c|c|c|c|}
\hline \multirow[b]{3}{*}{ VARIABLES } & \multicolumn{4}{|c|}{ Urban Area } & \multicolumn{4}{|c|}{ Rural Area } \\
\hline & \multicolumn{4}{|c|}{ Treat-Selection } & \multirow[b]{2}{*}{ Probit } & \multirow[b]{2}{*}{ IV Probit } & \multicolumn{2}{|c|}{ Treat-Selection } \\
\hline & Probit & IV Probit & LPM & Selec EQ & & & LPM & Selec EQ \\
\hline \multirow[t]{2}{*}{ Age } & $-0.0254 * * *$ & $-0.0253 * * *$ & $-0.0389 * * *$ & & $-0.0102 *$ & $-0.0112 * *$ & $-0.0181 * *$ & \\
\hline & $(0.00608)$ & $(0.00619)$ & $(0.00797)$ & & $(0.00526)$ & $(0.00527)$ & $(0.00706)$ & \\
\hline \multirow[t]{2}{*}{ Age Squared } & $0.000262 * * *$ & $0.000261 * * *$ & $0.000455^{* * *}$ & & 0.000103 & 0.000118 & $0.000217^{* *}$ & \\
\hline & $(9.03 e-05)$ & $(9.16 \mathrm{e}-05)$ & $(0.000110)$ & & $(7.34 \mathrm{e}-05)$ & $(7.31 \mathrm{e}-05)$ & $(9.42 \mathrm{e}-05)$ & \\
\hline \multirow[t]{2}{*}{ Years of education } & 0.00100 & 0.00107 & 0.00103 & $-0.00885^{*}$ & 0.000626 & 0.000764 & 0.00103 & -0.00799 \\
\hline & $(0.00225)$ & $(0.00226)$ & $(0.00223)$ & $(0.00522)$ & $(0.00175)$ & $(0.00175)$ & $(0.00201)$ & $(0.00741)$ \\
\hline \multirow[t]{2}{*}{ Currently Pregnant } & $0.0533^{*}$ & $0.0545^{*}$ & $0.0649 *$ & -0.105 & $0.0750 * * *$ & $0.0817 * * *$ & $0.0883^{* * *}$ & $-0.301 * *$ \\
\hline & $(0.0290)$ & $(0.0297)$ & $(0.0340)$ & $(0.0834)$ & $(0.0275)$ & $(0.0296)$ & $(0.0296)$ & $(0.119)$ \\
\hline \multirow[t]{2}{*}{ Income $Q=2$} & -0.0423 & -0.0438 & -0.0507 & & 0.0190 & 0.0171 & 0.0210 & \\
\hline & $(0.0388)$ & $(0.0378)$ & $(0.0630)$ & & $(0.0126)$ & $(0.0128)$ & $(0.0139)$ & \\
\hline Income $Q=3$ & 0.00695 & 0.00577 & 0.000966 & & 0.0417 & 0.0403 & 0.0332 & \\
\hline & $(0.0538)$ & $(0.0530)$ & $(0.0654)$ & & $(0.0302)$ & $(0.0297)$ & $(0.0265)$ & \\
\hline Income $Q=4$ & -0.0221 & -0.0234 & -0.0312 & & -0.00791 & -0.00877 & -0.0247 & \\
\hline & $(0.0505)$ & $(0.0499)$ & $(0.0659)$ & & $(0.0223)$ & $(0.0226)$ & $(0.0286)$ & \\
\hline Income $Q=5$ & -0.0251 & -0.0248 & -0.0308 & & $-0.0510^{* * *}$ & $-0.0524 * * *$ & $-0.0648^{* *}$ & \\
\hline & $(0.0521)$ & $(0.0520)$ & $(0.0681)$ & & $(0.00874)$ & $(0.00924)$ & $(0.0283)$ & \\
\hline No of Children 6 years or older & 0.00247 & 0.00185 & 0.00201 & & $0.00597^{*}$ & $0.00584 *$ & 0.00462 & \\
\hline & $(0.00432)$ & $(0.00424)$ & $(0.00366)$ & & $(0.00343)$ & $(0.00347)$ & $(0.00305)$ & \\
\hline No of Children 5 years or younger & -0.00403 & -0.00372 & -0.00705 & & 0.00685 & 0.00713 & 0.00740 & \\
\hline & $(0.00878)$ & $(0.00869)$ & $(0.00950)$ & & $(0.00521)$ & $(0.00523)$ & $(0.00662)$ & \\
\hline Region 2 & -0.0286 & -0.0304 & -0.0291 & & $-0.0849 * * *$ & $-0.0838^{* * *}$ & $-0.141 * * *$ & \\
\hline & $(0.0261)$ & $(0.0264)$ & $(0.0266)$ & & $(0.0112)$ & $(0.0113)$ & $(0.0286)$ & \\
\hline Region 3 & -0.0130 & -0.0147 & -0.0155 & & $-0.0577 * * *$ & $-0.0553^{* * *}$ & $-0.106^{* * *}$ & \\
\hline & $(0.0260)$ & $(0.0262)$ & $(0.0264)$ & & $(0.0120)$ & $(0.0122)$ & $(0.0293)$ & \\
\hline Region 4 & 0.00976 & 0.00801 & 0.00372 & & $-0.0549 * * *$ & $-0.0552 * * *$ & $-0.136^{* * *}$ & \\
\hline & $(0.0313)$ & $(0.0313)$ & $(0.0294)$ & & $(0.00724)$ & $(0.00757)$ & $(0.0293)$ & \\
\hline Region 5 & 0.0199 & 0.0181 & 0.0198 & & $-0.0416^{* * *}$ & $-0.0407 * * *$ & $-0.0894 * * *$ & \\
\hline & $(0.0365)$ & $(0.0366)$ & $(0.0343)$ & & $(0.0125)$ & $(0.0130)$ & $(0.0346)$ & \\
\hline Region 6 & 0.0370 & 0.0345 & 0.0306 & & -0.0182 & -0.0161 & -0.0379 & \\
\hline & $(0.0342)$ & $(0.0342)$ & $(0.0295)$ & & $(0.0219)$ & $(0.0228)$ & $(0.0518)$ & \\
\hline Region 7 & $0.0519 *$ & $0.0510^{*}$ & $0.0518^{* *}$ & & 0.0100 & 0.0152 & 0.0304 & \\
\hline & $(0.0297)$ & $(0.0297)$ & $(0.0261)$ & & $(0.0195)$ & $(0.0205)$ & $(0.0359)$ & \\
\hline Region 8 & -0.00245 & -0.00268 & -0.00158 & & $-0.0405^{* * *}$ & $-0.0400^{* * *}$ & $-0.0937 * *$ & \\
\hline & $(0.0293)$ & $(0.0291)$ & $(0.0277)$ & & $(0.0117)$ & $(0.0123)$ & $(0.0425)$ & \\
\hline Region 9 & $0.115^{* *}$ & $0.116^{* *}$ & $0.120^{* * *}$ & & 0.00996 & 0.0214 & 0.0352 & \\
\hline & $(0.0557)$ & $(0.0546)$ & $(0.0440)$ & & $(0.0364)$ & $(0.0425)$ & $(0.0630)$ & \\
\hline Age at first marriage & 0.00215 & 0.00224 & 0.00212 & $-0.0922 * * *$ & 0.000277 & 0.000337 & 0.000242 & $-0.0800^{*}$ \\
\hline & $(0.00154)$ & $(0.00155)$ & $(0.00136)$ & $(0.0347)$ & $(0.00150)$ & $(0.00153)$ & $(0.00136)$ & $(0.0441)$ \\
\hline Husband works & 0.00766 & 0.00989 & 0.00758 & & 0.00319 & 0.00458 & 0.00672 & \\
\hline & $(0.0287)$ & $(0.0285)$ & $(0.0314)$ & & $(0.0347)$ & $(0.0350)$ & $(0.0461)$ & \\
\hline Husband Age & 0.000352 & 0.000367 & $5.96 \mathrm{e}-05$ & & -0.00116 & -0.00118 & -0.00103 & \\
\hline & $(0.00138)$ & $(0.00138)$ & $(0.00139)$ & & $(0.000827)$ & $(0.000846)$ & $(0.000872)$ & \\
\hline Husband Education & -0.000398 & -0.000376 & -0.000280 & & 0.000355 & 0.000371 & 0.000426 & \\
\hline & $(0.000544)$ & $(0.000543)$ & $(0.000457)$ & & $(0.000335)$ & $(0.000347)$ & $(0.000503)$ & \\
\hline Indigenous & 0.00742 & 0.00797 & 0.00941 & & 0.00830 & 0.0109 & 0.0199 & \\
\hline & $(0.0173)$ & $(0.0173)$ & $(0.0167)$ & & $(0.0138)$ & $(0.0138)$ & $(0.0204)$ & \\
\hline Poverty Level & $6.21 \mathrm{e}-05$ & $5.77 \mathrm{e}-05$ & $-7.80 \mathrm{e}-06$ & & -0.000157 & -0.000159 & -0.000330 & \\
\hline & $(0.000439)$ & $(0.000439)$ & $(0.000439)$ & & $(0.000524)$ & $(0.000523)$ & $(0.000640)$ & \\
\hline Violence & $0.0269 * *$ & 0.0487 & $0.0666^{*}$ & & $0.0173^{*}$ & $0.0446^{*}$ & $0.0484 * *$ & \\
\hline & $(0.0118)$ & $(0.0369)$ & $(0.0342)$ & & $(0.00995)$ & $(0.0240)$ & $(0.0230)$ & \\
\hline Reg. Violence & & & & $2.845^{* * *}$ & & & & $2.960 * * *$ \\
\hline & & & & $(0.139)$ & & & & $(0.0966)$ \\
\hline Intergenerational Violence & & & & $0.263^{* * *}$ & & & & $0.281 * * *$ \\
\hline & & & & $(0.0547)$ & & & & $(0.0552)$ \\
\hline Accepts Violence & & & & $0.185^{* *}$ & & & & $0.229 * * *$ \\
\hline & & & & $(0.0720)$ & & & & $(0.0758)$ \\
\hline Age at first Marriage ${ }^{\wedge} 2$ & & & & $0.00178^{* *}$ & & & & $0.00168^{*}$ \\
\hline & & & & $(0.000758)$ & & & & $(0.000984)$ \\
\hline Constant & & & $0.798^{* * *}$ & -0.378 & & & $0.478^{* * *}$ & -0.703 \\
\hline & & & $(0.160)$ & $(0.384)$ & & & $(0.134)$ & $(0.489)$ \\
\hline Exogeneity Test (chi2 k=1) & & $0.39(\mathrm{p}=0.534)$ & & & & $1.33(\mathrm{p}=0.249$ & & \\
\hline Observations & 4,456 & 4,456 & 4,453 & 4,453 & 2,639 & 2,639 & 2,639 & 2,639 \\
\hline
\end{tabular}


Table A2.8. Determinants of Job exit, Entire Sample and Different corrections. By Ethnicity

\begin{tabular}{|c|c|c|c|c|c|c|c|c|}
\hline \multirow[b]{2}{*}{ VARIABLES } & \multicolumn{6}{|c|}{ Treat-Selection } & \multicolumn{2}{|c|}{ Treat-Selection } \\
\hline & Probit & IV Probit & LPM & Selec EQ & Probit & IV Probit & LPM & Selec EQ \\
\hline \multirow[t]{2}{*}{ Age } & $-0.0144 * *$ & $-0.0155^{* * *}$ & $-0.0271 * * *$ & & $-0.0249 * * *$ & $-0.0249 * * *$ & $-0.0351 * * *$ & \\
\hline & $(0.00561)$ & $(0.00576)$ & $(0.00867)$ & & $(0.00581)$ & $(0.00582)$ & $(0.00705)$ & \\
\hline \multirow[t]{2}{*}{ Age Squared } & $0.000130 *$ & $0.000144^{*}$ & $0.000307^{* * *}$ & & $0.000269^{* * *}$ & $0.000270^{* * *}$ & $0.000418^{* * *}$ & \\
\hline & $(7.76 \mathrm{e}-05)$ & $(8.00 \mathrm{e}-05)$ & $(0.000113)$ & & $(8.70 \mathrm{e}-05)$ & $(8.70 \mathrm{e}-05)$ & $(9.89 \mathrm{e}-05)$ & \\
\hline \multirow[t]{2}{*}{ Years of education } & 0.00147 & 0.00133 & 0.00207 & -0.00502 & 0.000273 & 0.000383 & 0.000390 & $-0.0139 * *$ \\
\hline & $(0.00210)$ & $(0.00210)$ & $(0.00264)$ & $(0.00831)$ & $(0.00226)$ & $(0.00225)$ & $(0.00216)$ & $(0.00600)$ \\
\hline \multirow[t]{2}{*}{ Currently Pregnant } & $0.0530^{*}$ & $0.0577 * *$ & $0.0686^{* *}$ & $-0.337 * * *$ & $0.0669 * *$ & $0.0679 * *$ & $0.0765^{* *}$ & -0.0374 \\
\hline & $(0.0279)$ & $(0.0291)$ & $(0.0345)$ & $(0.105)$ & $(0.0292)$ & $(0.0296)$ & $(0.0325)$ & $(0.0924)$ \\
\hline \multirow[t]{2}{*}{ Income $Q=2$} & 0.0199 & 0.0175 & 0.0192 & & -0.0180 & -0.0183 & -0.0225 & \\
\hline & $(0.0169)$ & $(0.0172)$ & $(0.0145)$ & & $(0.0225)$ & $(0.0223)$ & $(0.0269)$ & \\
\hline \multirow[t]{2}{*}{ Income $Q=3$} & $0.0800^{* *}$ & $0.0783^{* *}$ & $0.0684 * * *$ & & $4.86 \mathrm{e}-05$ & -0.000259 & -0.00119 & \\
\hline & $(0.0312)$ & $(0.0312)$ & $(0.0236)$ & & $(0.0287)$ & $(0.0285)$ & $(0.0316)$ & \\
\hline \multirow[t]{2}{*}{ Income $Q=4$} & $0.0578^{*}$ & 0.0561 & 0.0430 & & -0.0302 & -0.0304 & -0.0365 & \\
\hline & $(0.0348)$ & $(0.0343)$ & $(0.0268)$ & & $(0.0287)$ & $(0.0285)$ & $(0.0343)$ & \\
\hline \multirow[t]{2}{*}{ Income $\mathrm{Q}=5$} & 0.0623 & 0.0585 & 0.0395 & & -0.0339 & -0.0329 & -0.0374 & \\
\hline & $(0.0624)$ & $(0.0619)$ & $(0.0479)$ & & $(0.0329)$ & $(0.0334)$ & $(0.0387)$ & \\
\hline \multirow[t]{2}{*}{ No of Children 6 years or older } & $0.00591 *$ & 0.00562 & $0.00504^{*}$ & & 0.00479 & 0.00443 & 0.00368 & \\
\hline & $(0.00333)$ & $(0.00343)$ & $(0.00275)$ & & $(0.00491)$ & $(0.00488)$ & $(0.00454)$ & \\
\hline \multirow[t]{2}{*}{ No of Children 5 years or younger } & 0.00701 & 0.00738 & 0.00563 & & -0.00568 & -0.00549 & -0.00918 & \\
\hline & $(0.00542)$ & $(0.00547)$ & $(0.00685)$ & & $(0.0102)$ & $(0.0102)$ & $(0.0108)$ & \\
\hline Region 2 & $-0.0686^{* * *}$ & $-0.0683^{* * *}$ & $-0.0939 * * *$ & & $-0.0577 * *$ & $-0.0577 * *$ & $-0.0586^{* *}$ & \\
\hline & $(0.0151)$ & $(0.0151)$ & (0.0298) & & $(0.0235)$ & $(0.0235)$ & $(0.0276)$ & \\
\hline Region 3 & $-0.0476 * * *$ & $-0.0469 * * *$ & $-0.0763 * * *$ & & -0.0274 & -0.0273 & -0.0242 & \\
\hline & (0.0144) & $(0.0145)$ & $(0.0296)$ & & $(0.0255)$ & $(0.0255)$ & $(0.0285)$ & \\
\hline Region 4 & $-0.0513 * * *$ & -0.0516 *** & $-0.102^{* * *}$ & & -0.00897 & -0.00915 & -0.00858 & \\
\hline & $(0.00932)$ & $(0.00969)$ & $(0.0315)$ & & $(0.0283)$ & $(0.0283)$ & $(0.0305)$ & \\
\hline Region 5 & -0.0217 & -0.0216 & -0.0413 & & -0.0398 & -0.0400 & -0.0376 & \\
\hline & $(0.0172)$ & $(0.0175)$ & $(0.0348)$ & & $(0.0247)$ & $(0.0248)$ & $(0.0307)$ & \\
\hline Region 6 & 0.00929 & 0.0112 & 0.0271 & & 0.000457 & 0.000289 & 0.00203 & \\
\hline & $(0.0363)$ & $(0.0367)$ & $(0.0670)$ & & $(0.0276)$ & $(0.0275)$ & $(0.0282)$ & \\
\hline Region 7 & 0.00130 & 0.00452 & 0.00785 & & 0.0302 & 0.0311 & 0.0385 & \\
\hline & $(0.0223)$ & $(0.0232)$ & $(0.0409)$ & & $(0.0258)$ & $(0.0257)$ & $(0.0255)$ & \\
\hline Region 8 & $-0.0580 * * *$ & $-0.0586^{* * *}$ & $-0.125^{* * *}$ & & -0.0322 & -0.0315 & -0.0260 & \\
\hline & $(0.00795)$ & $(0.00870)$ & $(0.0374)$ & & $(0.0231)$ & $(0.0230)$ & $(0.0274)$ & \\
\hline Region 9 & -0.00851 & -0.00172 & 0.0128 & & $0.0780^{*}$ & $0.0816^{*}$ & $0.0971 * *$ & \\
\hline & $(0.0608)$ & $(0.0705)$ & $(0.121)$ & & $(0.0452)$ & $(0.0455)$ & $(0.0398)$ & \\
\hline Age at first marriage & 0.00120 & 0.00126 & 0.00110 & $-0.119 * * *$ & 0.00235 & 0.00244 & 0.00238 & -0.0386 \\
\hline & $(0.00147)$ & $(0.00150)$ & $(0.00135)$ & $(0.0406)$ & $(0.00186)$ & $(0.00186)$ & $(0.00165)$ & $(0.0383)$ \\
\hline Husband works & $0.0443^{* * *}$ & $0.0482^{* * *}$ & $0.0571 * * *$ & & -0.0171 & -0.0169 & -0.0179 & \\
\hline & $(0.0132)$ & $(0.0128)$ & $(0.0205)$ & & $(0.0355)$ & $(0.0354)$ & $(0.0381)$ & \\
\hline Husband Age & $4.16 \mathrm{e}-05$ & $-3.93 e-06$ & $5.39 \mathrm{e}-05$ & & -0.000357 & -0.000331 & -0.000605 & \\
\hline & $(0.000966)$ & $(0.000980)$ & $(0.00107)$ & & $(0.00130)$ & $(0.00131)$ & $(0.00127)$ & \\
\hline Husband Education & 0.000130 & 0.000141 & $3.99 \mathrm{e}-05$ & & $8.39 \mathrm{e}-05$ & 0.000105 & 0.000182 & \\
\hline & $(0.000328)$ & $(0.000336)$ & $(0.000356)$ & & $(0.000677)$ & $(0.000672)$ & $(0.000816)$ & \\
\hline Urban area & 0.0227 & 0.0201 & 0.0241 & & $0.0311 *$ & $0.0307 *$ & $0.0333 *$ & \\
\hline & $(0.0165)$ & $(0.0166)$ & $(0.0171)$ & & $(0.0169)$ & $(0.0170)$ & $(0.0200)$ & \\
\hline Poverty Level & 0.000593 & 0.000565 & 0.000554 & & -0.000121 & -0.000110 & -0.000191 & \\
\hline & $(0.000420)$ & $(0.000424)$ & $(0.000497)$ & & $(0.000493)$ & $(0.000493)$ & $(0.000499)$ & \\
\hline Violence & 0.00969 & 0.0405 & 0.0370 & & $0.0390^{* * *}$ & 0.0545 & $0.0778^{* *}$ & \\
\hline & $(0.0102)$ & $(0.0302)$ & $(0.0278)$ & & $(0.0121)$ & $(0.0362)$ & $(0.0339)$ & \\
\hline Reg. Violence & & & & $2.987 * * *$ & & & & $2.804 * * *$ \\
\hline & & & & $(0.130)$ & & & & $(0.136)$ \\
\hline Intergenerational Violence & & & & $0.331 * * *$ & & & & $0.213^{* * *}$ \\
\hline & & & & $(0.0546)$ & & & & $(0.0626)$ \\
\hline Accepts Violence & & & & $0.209 * * *$ & & & & $0.189 * * *$ \\
\hline & & & & $(0.0772)$ & & & & $(0.0675)$ \\
\hline Age at first Marriage ${ }^{\wedge} 2$ & & & & $0.00267 * * *$ & & & & 0.000468 \\
\hline & & & & $(0.000878)$ & & & & $(0.000857)$ \\
\hline Constant & & & $0.478^{* * *}$ & -0.392 & & & $0.748 * * *$ & $-0.795^{*}$ \\
\hline & & & $(0.160)$ & $(0.458)$ & & & $(0.139)$ & $(0.419)$ \\
\hline Exogeneity Test (chi2 k=1) & & & & & & & & \\
\hline Observations & 2,946 & 2,946 & 2,944 & 2,944 & 4,149 & 4,149 & 4,148 & 4,148 \\
\hline
\end{tabular}


Table A2.9. Determinants of Job exit, IV and Selection correction, Indigenous people, by quintile of income

\begin{tabular}{|c|c|c|c|c|c|c|c|c|c|c|c|c|}
\hline \multirow[b]{2}{*}{ VARIABLES } & \multicolumn{3}{|c|}{ Q1 } & \multicolumn{3}{|c|}{ Q2 } & \multicolumn{3}{|c|}{ Q3 } & \multicolumn{3}{|c|}{ Q4-Q5 } \\
\hline & \multicolumn{3}{|c|}{ Treat-Selection } & \multicolumn{3}{|c|}{ Treat-Selection } & \multicolumn{3}{|c|}{ Treat-Selection } & IV Probit & \multicolumn{2}{|c|}{ Treat-Selection } \\
\hline \multirow{2}{*}{ Age } & & & & & & & & & & & & \\
\hline & $\begin{array}{l}-0.0116 \\
(0.00750)\end{array}$ & $\begin{array}{l}-0.0169 \\
(0.0108)\end{array}$ & & $\begin{array}{l}-0.0108 \\
(0.00739)\end{array}$ & $\begin{array}{c}-0.0195^{*} \\
(0.0118)\end{array}$ & & $\begin{array}{c}-0.0372^{* *} \\
(0.0170)\end{array}$ & $\begin{array}{c}-0.0491 * * \\
(0.0221)\end{array}$ & & $\begin{array}{l}-0.0118 \\
(0.0128)\end{array}$ & $\begin{array}{l}-0.0413^{*} \\
(0.0227)\end{array}$ & \\
\hline \multirow{2}{*}{ Age Squared } & 0.000116 & 0.000194 & & $6.64 \mathrm{e}-05$ & 0.000195 & & $0.000399^{*}$ & $0.000547 *$ & & 0.000128 & $0.000502^{*}$ & \\
\hline & $(0.000105)$ & $(0.000145)$ & & $(0.000103)$ & $(0.000154)$ & & $(0.000234)$ & $(0.000280)$ & & $(0.000180)$ & $(0.000298)$ & \\
\hline \multirow[t]{2}{*}{ Years of education } & 0.00649 & 0.00752 & -0.00707 & -0.000243 & -0.000614 & -0.0115 & -0.000377 & 0.00147 & -0.0208 & 0.00150 & 0.000350 & 0.0170 \\
\hline & $(0.00408)$ & $(0.00500)$ & $(0.0207)$ & $(0.00203)$ & $(0.00293)$ & $(0.0161)$ & $(0.00504)$ & $(0.00577)$ & $(0.0177)$ & $(0.00396)$ & $(0.00496)$ & $(0.0149)$ \\
\hline \multirow[t]{2}{*}{ Currently Pregnant } & 0.0320 & 0.0419 & $-0.429 * *$ & 0.0749 & $0.105^{*}$ & $-0.402 * *$ & 0.0977 & 0.129 & -0.150 & -0.00991 & -0.0168 & 0.146 \\
\hline & $(0.0303)$ & $(0.0376)$ & $(0.184)$ & $(0.0456)$ & $(0.0593)$ & $(0.178)$ & $(0.104)$ & $(0.132)$ & $(0.299)$ & $(0.0495)$ & $(0.0764)$ & $(0.278)$ \\
\hline No of Children 6 years or older & $0.00813^{*}$ & 0.00550 & & 0.00610 & 0.00352 & & 0.0121 & 0.0145 & & -0.0112 & -0.00803 & \\
\hline & $(0.00490)$ & $(0.00413)$ & & $(0.00380)$ & $(0.00373)$ & & $(0.0135)$ & $(0.0105)$ & & $(0.00713)$ & $(0.00555)$ & \\
\hline No of Children 5 years or younger & 0.0108 & 0.00818 & & $0.0133^{*}$ & 0.0163 & & 0.00116 & -0.00216 & & -0.0218 & -0.0281 & \\
\hline & $(0.00759)$ & $(0.00821)$ & & $(0.00706)$ & $(0.0119)$ & & $(0.0162)$ & $(0.0199)$ & & $(0.0188)$ & $(0.0225)$ & \\
\hline Region 2 & $-0.0899 * * *$ & $-0.188 * * *$ & & $-0.0392^{*}$ & -0.0332 & & $-0.0872^{*}$ & -0.117 & & -0.0136 & -0.0115 & \\
\hline & $(0.0191)$ & $(0.0443)$ & & $(0.0226)$ & $(0.0294)$ & & $(0.0522)$ & $(0.0896)$ & & $(0.0472)$ & $(0.0649)$ & \\
\hline Region 3 & $-0.0614 * * *$ & $-0.138 * * *$ & & -0.00663 & -0.00106 & & $-0.0995 * *$ & $-0.147^{*}$ & & -0.0519 & -0.0576 & \\
\hline & $(0.0200)$ & $(0.0469)$ & & $(0.0221)$ & $(0.0319)$ & & $(0.0410)$ & $(0.0894)$ & & $(0.0397)$ & $(0.0556)$ & \\
\hline Region 4 & & $-0.213^{* * * *}$ & & 0.00483 & 0.0111 & & $-0.0889 * * * *$ & -0.148 & & -0.0206 & -0.0230 & \\
\hline Non & & $(0.0444)$ & & $(0.0297)$ & $(0.0396)$ & & $(0.0313)$ & $(0.0906)$ & & $(0.0563)$ & $(0.0819)$ & \\
\hline Region 5 & $-0.0511 * * *$ & $-0.141 * * *$ & & 0.0114 & 0.0313 & & 0.0579 & 0.0630 & & -0.0391 & -0.0398 & \\
\hline & $(0.0143)$ & $(0.0530)$ & & $(0.0308)$ & $(0.0415)$ & & $(0.0752)$ & $(0.104)$ & & $(0.0332)$ & $(0.0660)$ & \\
\hline Region 6 & & $-0.122^{*}$ & & 0.224 & $0.344 * *$ & & 0.0919 & 0.0827 & & -0.0235 & -0.0440 & \\
\hline & & $(0.0682)$ & & $(0.161)$ & $(0.170)$ & & $(0.121)$ & $(0.138)$ & & $(0.0348)$ & $(0.0654)$ & \\
\hline Region 7 & -0.00978 & -0.0403 & & 0.128 & $0.199 * *$ & & -0.0581 & -0.112 & & 0.0116 & 0.0303 & \\
\hline & $(0.0239)$ & $(0.0677)$ & & $(0.0880)$ & $(0.0834)$ & & $(0.0448)$ & $(0.0991)$ & & $(0.0486)$ & $(0.0695)$ & \\
\hline Region 8 & & $-0.199 * * *$ & & & -0.0238 & & & $-0.222 * *$ & & -0.0459 & -0.0145 & \\
\hline & & $(0.0509)$ & & & $(0.0435)$ & & & $(0.104)$ & & $(0.0312)$ & $(0.0811)$ & \\
\hline Region 9 & & $-0.135 * *$ & & & -0.106 & & 0.183 & 0.242 & & & 0.0103 & \\
\hline & & $(0.0560)$ & & & $(0.0824)$ & & $(0.361)$ & $(0.323)$ & & & $(0.0701)$ & \\
\hline Age at first marriage & 0.00159 & 0.00125 & $-0.161 * *$ & 0.00207 & 0.00154 & -0.0455 & $0.00995^{* *}$ & $0.00881 *$ & 0.0315 & -0.00468 & -0.00249 & $-0.335 * * *$ \\
\hline & $(0.00223)$ & $(0.00209)$ & $(0.0770)$ & $(0.00167)$ & $(0.00169)$ & $(0.0738)$ & $(0.00505)$ & $(0.00493)$ & $(0.117)$ & $(0.00310)$ & $(0.00204)$ & $(0.0849)$ \\
\hline Husband works & & $0.0920^{*}$ & & 0.0225 & 0.0280 & & 0.0664 & 0.0393 & & & $0.118^{* * * *}$ & \\
\hline & & $(0.0542)$ & & $(0.0187)$ & $(0.0375)$ & & $(0.0466)$ & $(0.0753)$ & & & $(0.0436)$ & \\
\hline Husband Age & -0.000168 & 0.000474 & & 0.00171 & 0.00206 & & -0.00145 & 0.000529 & & -0.00174 & -0.00206 & \\
\hline & $(0.000965)$ & $(0.00107)$ & & $(0.00129)$ & $(0.00188)$ & & $(0.00302)$ & $(0.00315)$ & & $(0.00238)$ & $(0.00227)$ & \\
\hline Husband Education & 0.000297 & 0.000309 & & 0.000524 & 0.000813 & & $-6.19 \mathrm{e}-05$ & 0.000102 & & $-0.00151 * *$ & $-0.000906 * *$ & \\
\hline & $(0.000364)$ & $(0.000597)$ & & $(0.000416)$ & $(0.000775)$ & & $(0.00109)$ & $(0.000786)$ & & $(0.000633)$ & $(0.000366)$ & \\
\hline Urban area & & $-0.0629 * *$ & & -0.00215 & -0.00927 & & 0.0266 & 0.0305 & & $0.0608 * * *$ & $0.0524 * *$ & \\
\hline & & $(0.0286)$ & & $(0.0157)$ & $(0.0227)$ & & $(0.0352)$ & $(0.0330)$ & & $(0.0195)$ & $(0.0260)$ & \\
\hline Poverty Level & $\begin{array}{c}0.00133 \\
(0.00108)\end{array}$ & $\begin{array}{c}0.00124 \\
(0.00103)\end{array}$ & & $\begin{array}{c}0.000286 \\
(0.000581)\end{array}$ & $\begin{array}{l}0.000393 \\
0.000821)\end{array}$ & & $\begin{array}{r}0.000542 \\
(0.000851)\end{array}$ & $\begin{array}{r}0.000429 \\
(0.000755)\end{array}$ & & -0.000990 & $\begin{array}{l}-0.000875 \\
0.000861)\end{array}$ & \\
\hline Violence & 0.00382 & 0.0213 & & 0.0358 & 0.0235 & & 0.0771 & 0.0223 & & 0.0586 & 0.102 & \\
\hline & $(0.0326)$ & $(0.0273)$ & & $(0.0285)$ & $(0.0492)$ & & $(0.0992)$ & $(0.0890)$ & & $(0.0873)$ & $(0.112)$ & \\
\hline Income $\mathrm{Q}=4$ & & & & & & & & & & 0.0114 & 0.00277 & \\
\hline Reg. Violence & & & $3.068 * * *$ & & & $3.165^{* * * *}$ & & & $2.898 * * *$ & (0.0541) & & $2.616 * * *$ \\
\hline & & & $(0.194)$ & & & $(0.311)$ & & & $(0.362)$ & & & $(0.408)$ \\
\hline Intergenerational Violence & & & $0.203^{* *}$ & & & $0.527 * * *$ & & & $0.411 * * *$ & & & 0.166 \\
\hline & & & $(0.0959)$ & & & $(0.120)$ & & & $(0.124)$ & & & $(0.150)$ \\
\hline Accepts Violence & & & $0.186^{*}$ & & & $0.254^{*}$ & & & 0.229 & & & 0.184 \\
\hline & & & $(0.112)$ & & & $(0.150)$ & & & $(0.176)$ & & & $(0.158)$ \\
\hline Age at first Marriage^2 & & & $0.00372^{* *}$ & & & 0.00120 & & & -0.000650 & & & $0.00664 * *$ \\
\hline & & & $(0.00170)$ & & & $(0.00163)$ & & & $(0.00263)$ & & & $(0.00178)$ \\
\hline Constant & & 0.227 & -0.0220 & & 0.273 & -1.288 & & $0.865^{* *}$ & -1.982 & & $0.928 * *$ & $2.497 * *$ \\
\hline & & $(0.204)$ & $(0.854)$ & & $(0.193)$ & $(0.878)$ & & $(0.411)$ & $(1.275)$ & & $(0.472)$ & $(1.017)$ \\
\hline athrho & & & -0.0818 & & & 0.00280 & & & -0.129 & & & -0.103 \\
\hline & & & $(0.0897)$ & & & $(0.143)$ & & & $(0.172)$ & & & $(0.235)$ \\
\hline Insigma & & & $\begin{array}{l}-1.482 * * * \\
(0.0882)\end{array}$ & & & $\begin{array}{l}-1.461 * * * \\
(0.0651)\end{array}$ & & & $\begin{array}{l}-1.155 * * * \\
(0.0539)\end{array}$ & & & $\begin{array}{l}-1.254 * * * \\
(0.0763)\end{array}$ \\
\hline Observations & 717 & 831 & 831 & 816 & 820 & 820 & 648 & 651 & 651 & 628 & 642 & 642 \\
\hline
\end{tabular}


Table A2.10. Determinants of Job exit, IV and Selection correction, Non-indigenous people, by quintile of income

\begin{tabular}{|c|c|c|c|c|c|c|c|c|c|c|c|c|}
\hline \multirow[b]{3}{*}{ VARIABLES } & \multicolumn{3}{|c|}{ Q1-Q2 } & \multicolumn{3}{|c|}{ Q3 } & \multicolumn{3}{|c|}{ Q4 } & \multicolumn{3}{|c|}{ Q5 } \\
\hline & \multirow{2}{*}{\multicolumn{3}{|c|}{$\begin{array}{ll} & \text { Treat-Selection } \\
\text { PM } & \text { Selec EQ }\end{array}$}} & \multicolumn{3}{|c|}{ Treat-Selection } & \multicolumn{3}{|c|}{ Treat-Selection } & \multicolumn{3}{|c|}{ Treat-Selection } \\
\hline & & & & IV Probit & LPM & Selec EQ & IV Probit & LPM & Selec EQ & IV Probit & LPM & Selec EQ \\
\hline \multirow[t]{2}{*}{ Age } & $-0.0176^{*}$ & $-0.0239 * *$ & & $-0.0456 * * *$ & $-0.0597 * * *$ & & $-0.0303 * * *$ & $-0.0377 * * *$ & & $-0.0198^{*}$ & $-0.0321 *$ & \\
\hline & $\begin{array}{l}(0.00937) \\
0.000280 * *\end{array}$ & $\begin{array}{l}(0.0121) \\
0.000364 * *\end{array}$ & & $(0.0151)$ & $(0.0178)$ & & $(0.0113)$ & $(0.0126)$ & & $(0.0105)$ & $(0.0168)$ & \\
\hline Age Squared & $\begin{array}{c}0.000280 * * \\
(0.000133)\end{array}$ & $\begin{array}{c}0.000364 * * \\
(0.000164)\end{array}$ & & $\begin{array}{c}0.000521 * * \\
(0.000255)\end{array}$ & $\begin{array}{c}0.000728 * * \\
(0.000288)\end{array}$ & & $\begin{array}{l}0.000327^{*} \\
(0.000167)\end{array}$ & $\begin{array}{c}0.000431 * * \\
(0.000177)\end{array}$ & & 0.000168 & $\begin{array}{r}0.000340 \\
0.000219\end{array}$ & \\
\hline \multirow[t]{2}{*}{ Years of education } & 0.00403 & 0.00362 & -0.0234 & -0.00149 & -0.00106 & 0.00161 & -0.000245 & -0.000345 & -0.0112 & 0.000520 & -0.000268 & -0.000988 \\
\hline & $(0.00330)$ & $(0.00358)$ & $(0.0154)$ & $(0.00389)$ & $(0.00375)$ & $(0.0160)$ & $(0.00339)$ & $(0.00335)$ & $(0.0135)$ & $(0.00424)$ & $(0.00458)$ & $(0.0145)$ \\
\hline \multirow[t]{2}{*}{ Currently Pregnant } & $0.188 * * *$ & $0.168 * * *$ & 0.0419 & 0.0461 & 0.0508 & 0.0879 & -0.0141 & -0.00841 & 0.0912 & 0.0794 & 0.0899 & $-0.443 * *$ \\
\hline & $(0.0552)$ & $(0.0536)$ & $(0.189)$ & $(0.0606)$ & $(0.0690)$ & $(0.229)$ & $(0.0403)$ & $(0.0538)$ & $(0.236)$ & $(0.0582)$ & $(0.0627)$ & $(0.195)$ \\
\hline No of Children 6 years or older & -0.00530 & -0.00529 & & 0.00981 & 0.00865 & & 0.000499 & 0.00140 & & 0.0133 & 0.0110 & \\
\hline & $(0.00739)$ & $(0.00792)$ & & $(0.0114)$ & $(0.00933)$ & & $(0.00943)$ & $(0.00741)$ & & $(0.00958)$ & $(0.0104)$ & \\
\hline No of Children 5 years or younger & 0.00771 & 0.00632 & & $-0.0412^{*}$ & $-0.0412^{*}$ & & -0.00755 & -0.00957 & & 0.00327 & 0.000881 & \\
\hline & $(0.0116)$ & $(0.0139)$ & & $(0.0229)$ & $(0.0224)$ & & $(0.0219)$ & $(0.0228)$ & & $(0.0163)$ & $(0.0199)$ & \\
\hline Region 2 & $-0.143 * * *$ & $-0.212 * * *$ & & -0.0324 & -0.0271 & & 0.00471 & -0.000627 & & -0.0109 & -0.0185 & \\
\hline & $(0.0233)$ & $(0.0610)$ & & $(0.0774)$ & $(0.0759)$ & & $(0.0574)$ & $(0.0451)$ & & $(0.0363)$ & $(0.0348)$ & \\
\hline Region 3 & $-0.0790 * * *$ & -0.0997 & & 0.000246 & 0.00540 & & 0.0729 & 0.0526 & & 0.00596 & -0.000347 & \\
\hline & $(0.0259)$ & $(0.0963)$ & & $(0.0817)$ & $(0.0785)$ & & $(0.0746)$ & $(0.0502)$ & & $(0.0421)$ & $(0.0369)$ & \\
\hline Region 4 & $-0.0900 * * *$ & $-0.158^{* *}$ & & 0.0582 & 0.0535 & & 0.0739 & 0.0574 & & -0.0102 & -0.0136 & \\
\hline & $(0.0180)$ & $(0.0684)$ & & $(0.0927)$ & $(0.0717)$ & & $(0.0824)$ & $(0.0562)$ & & $(0.0488)$ & $(0.0441)$ & \\
\hline Region 5 & $-0.0966^{* * * *}$ & $-0.220 * * *$ & & 0.0159 & 0.0290 & & 0.00760 & 0.0154 & & -0.0270 & -0.0187 & \\
\hline & $(0.0172)$ & $(0.0821)$ & & $(0.0822)$ & $(0.0731)$ & & $(0.0590)$ & $(0.0452)$ & & $(0.0380)$ & $(0.0361)$ & \\
\hline Region 6 & $-0.0764 * * *$ & $-0.123^{*}$ & & 0.0274 & 0.0270 & & 0.139 & $0.109 * *$ & & 0.00866 & 0.000223 & \\
\hline (a) & $(0.0282)$ & $(0.0678)$ & & $(0.0882)$ & $(0.0763)$ & & $(0.0850)$ & $(0.0517)$ & & $(0.0386)$ & $(0.0337)$ & \\
\hline Region 7 & -0.0203 & -0.0143 & & 0.00550 & 0.0128 & & $0.112^{*}$ & $0.101 * *$ & & $0.0897 * *$ & $0.0839 * *$ & \\
\hline & $(0.0396)$ & $(0.0623)$ & & $(0.0720)$ & $(0.0629)$ & & $(0.0611)$ & $(0.0451)$ & & $(0.0435)$ & $(0.0349)$ & \\
\hline Region 8 & $-0.0623 * *$ & -0.0861 & & -0.0568 & -0.0627 & & 0.00897 & 0.0158 & & -0.0320 & -0.0293 & \\
\hline & $(0.0309)$ & $(0.0689)$ & & $(0.0584)$ & $(0.0658)$ & & $(0.0601)$ & $(0.0440)$ & & $(0.0327)$ & $(0.0360)$ & \\
\hline Region 9 & 0.0319 & 0.0675 & & 0.0302 & 0.0408 & & 0.133 & 0.107 & & 0.149 & 0.132 & \\
\hline & $(0.0695)$ & $(0.0911)$ & & $(0.100)$ & $(0.0799)$ & & $(0.115)$ & $(0.0795)$ & & $(0.118)$ & $(0.0981)$ & \\
\hline Age at first marriage & 0.00108 & 0.00214 & 0.0311 & 0.00374 & 0.00375 & 0.0269 & $0.0103 * * *$ & $0.00947 * *$ & -0.0157 & -0.00324 & -0.00286 & $-0.153^{* *}$ \\
\hline & $(0.00328)$ & $(0.00345)$ & $(0.0765)$ & $(0.00507)$ & $(0.00478)$ & $(0.103)$ & $(0.00391)$ & $(0.00409)$ & $(0.0953)$ & $(0.00223)$ & $(0.00191)$ & $(0.0744)$ \\
\hline Husband works & 0.00307 & 0.0260 & & 0.0237 & 0.0329 & & 0.0353 & 0.0336 & & -0.0735 & -0.0744 & \\
\hline & $(0.0872)$ & $(0.112)$ & & $(0.0759)$ & $(0.0796)$ & & $(0.0469)$ & $(0.0617)$ & & $(0.0620)$ & $(0.0667)$ & \\
\hline Husband Age & $-0.00315^{*}$ & $-0.00354 * *$ & & -0.00104 & -0.00108 & & 0.00104 & 0.00127 & & 0.00125 & 0.00112 & \\
\hline & $(0.00179)$ & $(0.00178)$ & & $(0.00395)$ & $(0.00393)$ & & $(0.00230)$ & $(0.00255)$ & & $(0.00158)$ & $(0.00168)$ & \\
\hline Husband Education & -0.000602 & -0.000686 & & -0.000443 & -0.000191 & & 0.00134 & 0.00166 & & -0.000220 & -0.000246 & \\
\hline 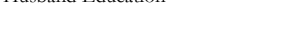 & $(0.000787)$ & $(0.000698)$ & & $(0.00147)$ & (0.00155) & & (0.00128) & $(0.00196)$ & & $(0.00159)$ & $(0.00180)$ & \\
\hline Urban area & -0.00698 & -0.00422 & & 0.0401 & 0.0338 & & 0.0421 & 0.0497 & & $0.0831 * * *$ & $0.122^{* * *}$ & \\
\hline & $(0.0242)$ & $(0.0277)$ & & $(0.0360)$ & $(0.0337)$ & & $(0.0344)$ & $(0.0431)$ & & $(0.0115)$ & $(0.0373)$ & \\
\hline Poverty Level & $-0.00190^{*}$ & $-0.00250^{*}$ & & -0.000752 & -0.000706 & & 0.00105 & 0.000937 & & 0.000864 & 0.000458 & \\
\hline & $(0.00104)$ & $(0.00141)$ & & $(0.00120)$ & $(0.00115)$ & & $(0.000915)$ & $(0.000951)$ & & $(0.000851)$ & $(0.000902)$ & \\
\hline Violence & $0.136^{* * * *}$ & $0.169 * * *$ & & 0.0978 & $0.161 * *$ & & 0.0811 & 0.0560 & & -0.0326 & -0.0188 & \\
\hline Income $\mathrm{Q}=4$ & $\begin{array}{l}(0.0473) \\
0.00199\end{array}$ & $\begin{array}{l}(0.0554) \\
0.000269\end{array}$ & & $(0.0937)$ & $(0.0797)$ & & $(0.0599)$ & $(0.0619)$ & & $(0.0533)$ & $(0.0806)$ & \\
\hline & $(0.0214)$ & $(0.0272)$ & & & & & & & & & & \\
\hline Reg. Violence & & & $2.494 * * *$ & & & $3.087 * * *$ & & & $3.160 * * *$ & & & $2.561 * * *$ \\
\hline Intercenerational Violence & & & $(0.268)$ & & & $(0.344)$ & & & $(0.319)$ & & & $(0.208)$ \\
\hline Intergenerational Violence & & & 0.0460 & & & $0.251^{* *}$ & & & $0.239 * *$ & & & $0.269 * * *$ \\
\hline & & & $(0.117)$ & & & $(0.125)$ & & & $(0.114)$ & & & $(0.0917)$ \\
\hline Accepts Violence & & & 0.167 & & & 0.236 & & & 0.183 & & & 0.126 \\
\hline & & & $(0.120)$ & & & $(0.145)$ & & & $(0.178)$ & & & $(0.156)$ \\
\hline Age at first Marriage^2 & & & -0.00106 & & & -0.000602 & & & -0.000227 & & & $0.00287 *$ \\
\hline & & & $(0.00183)$ & & & $(0.00238)$ & & & $(0.00213)$ & & & $(0.00156)$ \\
\hline Cosntant & & $0.712^{* * *}$ & -1.167 & & $1.126^{* * *}$ & $-1.935^{*}$ & & 0.392 & -1.216 & & $0.706^{* *}$ & 0.428 \\
\hline & & $(0.235)$ & $(0.831)$ & & $(0.353)$ & $(1.063)$ & & $(0.267)$ & $(1.037)$ & & $(0.355)$ & $(0.830)$ \\
\hline athrho & & & -0.134 & & & -0.189 & & & -0.0883 & & & 0.0543 \\
\hline & & & $(0.109)$ & & & $(0.130)$ & & & 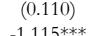 & & & $(0.174)$ \\
\hline Insigma & & & $\begin{array}{l}-1.132^{* * *} \\
(0.0404)\end{array}$ & & & $\begin{array}{c}-1.019 * * * \\
(0.0508)\end{array}$ & & & $\begin{array}{c}-1.115^{* * * *} \\
(0.0379)\end{array}$ & & & $\begin{array}{c}-1.206 * * * \\
(0.0432)\end{array}$ \\
\hline Observations & 934 & 934 & $\begin{array}{c}\left(\begin{array}{c}0.4004 \\
934\end{array}\right. \\
\end{array}$ & 869 & 869 & $\begin{array}{c}869 \\
\end{array}$ & 1,125 & 1,125 & 1,125 & 1,221 & 1,220 & 1,220 \\
\hline
\end{tabular}

Robust standard errors in parenthese
$* * * \mathrm{p}<0.01, * * \mathrm{p}<0.05, * \mathrm{p}<0.1$ 